2014s-24

\title{
The CCCTB option - an experimental study
}

\author{
Claudia Keser, Gerrit Kimpel, Andreas Oestreicher
}

\begin{tabular}{c}
\hline Série Scientifique \\
Scientific Series
\end{tabular}

\section{Montréal \\ Avril 2014}

(C) 2014 Claudia Keser, Gerrit Kimpel, Andreas Oestreicher. Tous droits réservés. All rights reserved.

Reproduction partielle permise avec citation du document source, incluant la notice $($ )

Short sections may be quoted without explicit permission, if full credit, including (C) notice, is given to the source.
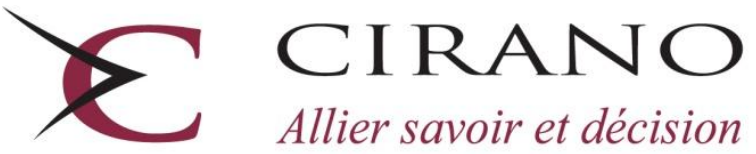

Allier savoir et décision

Centre interuniversitaire de recherche en analyse des organisations 


\section{CIRANO}

Le CIRANO est un organisme sans but lucratif constitué en vertu de la Loi des compagnies du Québec. Le financement de son infrastructure et de ses activités de recherche provient des cotisations de ses organisations-membres, d'une subvention d'infrastructure du Ministère de l'Enseignement supérieur, de la Recherche, de la Science et de la Technologie, de même que des subventions et mandats obtenus par ses équipes de recherche.

CIRANO is a private non-profit organization incorporated under the Québec Companies Act. Its infrastructure and research activities are funded through fees paid by member organizations, an infrastructure grant from the Ministère de l'Enseignement supérieur, de la Recherche, de la Science et de la Technologie, and grants and research mandates obtained by its research teams.

\section{Les partenaires du CIRANO}

\section{Partenaire majeur}

Ministère de l'Enseignement supérieur, de la Recherche, de la Science et de la Technologie

\section{Partenaires corporatifs}

Autorité des marchés financiers

Banque de développement du Canada

Banque du Canada

Banque Laurentienne du Canada

Banque Nationale du Canada

Banque Scotia

Bell Canada

BMO Groupe financier

Caisse de dépôt et placement du Québec

Fédération des caisses Desjardins du Québec

Financière Sun Life, Québec

Gaz Métro

Hydro-Québec

Industrie Canada

Intact

Investissements PSP

Ministère des Finances et de l'Économie

Power Corporation du Canada

Rio Tinto Alcan

Transat A.T.

Ville de Montréal

\section{Partenaires universitaires}

École Polytechnique de Montréal

École de technologie supérieure (ÉTS)

HEC Montréal

Institut national de la recherche scientifique (INRS)

McGill University

Université Concordia

Université de Montréal

Université de Sherbrooke

Université du Québec

Université du Québec à Montréal

Université Laval

Le CIRANO collabore avec de nombreux centres et chaires de recherche universitaires dont on peut consulter la liste sur son site web.

Les cahiers de la série scientifique (CS) visent à rendre accessibles des résultats de recherche effectuée au CIRANO afin de susciter échanges et commentaires. Ces cahiers sont écrits dans le style des publications scientifiques. Les idées et les opinions émises sont sous l'unique responsabilité des auteurs et ne représentent pas nécessairement les positions du CIRANO ou de ses partenaires.

This paper presents research carried out at CIRANO and aims at encouraging discussion and comment. The observations and viewpoints expressed are the sole responsibility of the authors. They do not necessarily represent positions of CIRANO or its partners. 


\title{
The CCCTB option - an experimental study
}

\author{
Claudia Keser ${ }^{*}$, Gerrit Kimpel ${ }^{*}$, Andreas Oestreicher ${ }^{*}$
}

\begin{abstract}
Résumé/abstract
The objective of this paper is to look into the probability that, given the choice, corporate groups would opt for taxation on a consolidated basis. Consolidation would allow them to offset losses crossborder but remove the opportunity to exploit international tax-rate differentials between entities via transfer pricing. We present a laboratory experiment in which we investigate to what extent a corporation would be inclined to take up the consolidation option and how this would impact on the corporation's location of investment and its transfer pricing activities involving locations outside the consolidated group. We use a 2-by-2 treatment design with two levels of tax-rate differential between two investment locations, and two different remuneration functions allowing the participants to act as owners or managers of a company.
\end{abstract}

Mots clés/key words : International company taxation, separate accounting, formula apportionment, transfer pricing, experimental economics.

Codes JEL : C91, H25, M41

\footnotetext{
* University of Göttingen, Department of Economics, Chair of microeconomics, Platz der Göttinger Sieben 3 , 37073 Göttingen, Germany, claudia.keser@uni-goettingen.de

${ }^{\dagger}$ University of Göttingen, Department of Business Administration, Tax Division, Platz der Göttinger Sieben 3, 37073 Göttingen, Germany, gerrit.kimpel@wiwi.uni-goettingen.de

$¥$ University of Göttingen, Department of Business Administration, Tax Division, Platz der Göttinger Sieben 3 , 37073 Göttingen, Germany, andreas.oestreicher@uni-goettingen.de
} 


\section{Introduction}

In March 2011 the European Commission submitted a draft directive proposing the introduction of a Common Consolidated Corporate Tax Base (European Commission, 2011). Under a CCСТВ the companies belonging to a corporate group would be allowed to file one single tax return and consolidate all the profits and losses they incur across the EU. The aim of this proposal is to remove existing tax obstacles to the development of the internal market. A main issue of the present system, in which corporations in the EU are taxed separately (separate accounting), concerns the high costs relating to compliance with transfer-price regulations according to the arm'slength principle. In addition, over-taxation arises in cross-border activities where a cross-border loss offset is only available under certain pre-conditions. What is more, the network of double taxation treaties grants businesses insufficient protection against double taxation since such treaties are designed to address bilateral relations.

Under a CCCTB the consolidated tax base would be shared out amongst the member states in which the corporation is active, according to a specific formula using a combination of tangible fixed assets, labor costs, employment, and sales by destination as the allocation key (formula apportionment). The CCCTB constitutes a form of group taxation allowing for a cross-border loss offset, which under the current system of separate accounting only applies locally in a small number of countries under very specific conditions. The CCCTB option thus offers some kind of institutional choice, under which the corporations concerned opt either for tax planning under separate accounting with no cross-border loss offset but the opportunity for profit shifts, or for cross-border loss offset with tax planning under formula apportionment. Under formula apportionment, corporations would lose opportunities for profit shifting, and we might expect consequences for investment (allocation of production factors) and the choice of location.

Our study investigates the acceptance and effects that introduction of an optional CCCTB would have on the allocation of investment and usage of specific tax-planning alternatives available under separate accounting and formula apportionment. In this case an optional CCCTB means that companies would not be forced to enter the new system, and hence to carry the costs of switching to this new regime.

Up to now, these questions have been examined only in part. Empirical investigations have been limited to the domestic context. The impact of 'institutional choices' has been subjected to scant examination as a whole. As a rule, these choices are made on 
the basis of a complex network of facts and circumstances, for which scarcely any data emerges that can be scrutinized. Research relating to profit shifting often neglects the possibility of potential losses in the analysis. ${ }^{1}$ Since we lack real-life data that would allow us to analyze the effect of an optional taxation on a consolidated basis, we use the method of experimental economics. The experimental method has an additional advantage. Psychological aspects can be investigated more easily in a controlled laboratory environment than in real-life data. Such aspects play an important role when it comes to decisions regarding taxes, as has already been pointed out by Schmölders (1960, 1970). . The controlled laboratory environment is of particular significance in our experiment due to the complexity of the issue under examination. Beyond behavioral anomalies that are often observed in cases of decisions made in a situation of uncertainty, we can investigate, how people deal with complexity extending beyond their cognitive limits (Simon, 1957).

Our experiment focuses on the choice of tax regime (separate accounting or formula apportionment), the allocation of production factors, and profit-shifting activities in the presence of uncertain returns on investment. In a 2-by-2 treatment design, we consider the impact of two levels of tax-rate differential and of a manager versus an owner compensation scheme. Several empirical investigations have shown that taxrate differentials impact on investment-location and transfer-pricing decisions (see Section 2 below). The remuneration scheme could play an important role since owners have to bear losses, while managers do not.

With respect to the proposed introduction of a CCCTB, we observe in our experiment that participants make use of taxation on a consolidated basis in a substantial number of cases, while at the same time they exploit the benefits of shifting profit to lower taxed investment alternatives outside the consolidated group. Furthermore, our experimental results suggest that the use of formula apportionment influences the allocation of economic values taken up in the allocation formula. These findings suggest that profit shifting will continue to take place and is carried out using the same avenues, i.e., allocation of assets to low taxed investment alternatives and shifting of "paper' profits. However, they also make it clear that formula apportionment provides an equivalent alternative tax regime since it offers intra-group loss-offset and, hence, brings with it tax advantages in cases that investments end up in a loss.

\footnotetext{
${ }^{1}$ The influence of taxation on investment under uncertainty is analyzed on a theoretical basis by Mackie-Mason, 1990; Alvarez, Kannianinen and Södersten, 1998; Sureth, 2002; Niemann and Sureth, 2004; Edmiston, 2004; Alvarez and Koskela, 2008; Gries, Prior and Sureth 2012.
} 
Our paper is structured as follows. Section 2 provides a brief survey of theoretical and empirical studies on tax-planning strategies under separate ac-counting and formula apportionment. In Section 3 we present a static model on the impact of the tax regime (separate accounting and formula apportionment) on the optimal allocation of production factors and tax planning activities making use of profit shifting to low-tax jurisdictions. Section 4 describes the experimental design and develops our research hypotheses. Section 5 brings out the results of our analysis. Section 6 concludes.

\section{Literature}

Institutional settings involving tax planning either under separate accounting or formula apportionment have been the object of a number of empirical investigations. Many of these investigate the impact of tax rates on choice of investment location and intra-group transfer pricing under separate accounting. Losses, the possibilities to off-set losses, or other non-debt tax shields ${ }^{2}$ have been granted relatively little attention, though.

Arachi and Biagi, 2005, Hanlon and Heitzman, 2010 and Feld and Heckemeyer, 2011, report on the impact of tax differentials on investment location decisions. Moreover, the possibilities of using tax differentials by way of transfer pricing are examined (1) directly on the basis of given market prices or transaction volumes (Bernard and Weiner, 1990; Swenson, 2001; Clausing, 2003), or (2) indirectly via reported profits or profitability, and are shown both for the USA (Grubert and Mutti, 1991; Harris, 1993; Klassen et al., 1993; Harris et al., 1993; Collins et al., 1998; Klassen and Laplante, 2012), and the OECD (Bartelsman and Beetsma, 2003) as well as for Europe (Huizinga and Laeven, 2008; Egger, Eggert and Winner, 2010 and Dharmapala and Riedel, 2013). 3

Devereux, 1989 and Devereux, Keen and Schiantarelli, 1994 consider the influence of asymmetric taxation of profits and losses on investment decisions. Dreßler and Overesch, 2013 deal with the impact of existing loss-carry forwards and the treatment of future losses on the extent of German outbound investment.

In the context of capital structure, the impact of any losses or loss carry-forwards has been largely neglected. In some cases this influence is taken into account using a bi-

\footnotetext{
${ }^{2}$ See, for example, the current OECD “Action Plan on Base Erosion and Profit Shifting" (OECD 2013a, 2013b) for more sophisticated approaches.

3 In the scope of a meta study Heckemeyer and Overesch, 2013 calculate a semi elasticity of EBIT in relation to the statutory tax rate of 1.3 .
} 
nary regression variable that controls for existence or non-existence of loss carryforwards (Ramb and Weichenrieder, 2005; Buettner, Overesch and Wamser, 2011).

In order to avoid generating distorted results, losses or tax loss carry-forwards are also, for the most part, also neglected or explicitly omitted from the analysis, also when it comes to looking into profit shifting via transfer pricing (Klassen et al., 1993; Huizinga and Laeven, 2008 and Dharmapala and Riedel, 2013). To our knowledge, only Creedy and Gemmel, 2011 have given specific scrutiny to loss-making companies up to now. These authors show analytically that tax-rate sensitivity of tax revenue decreases the more asymmetrical the tax system becomes.

Offsetting losses against profits is of central importance when businesses are deciding whether to opt for a group taxation regime, which allows for domestic intra-group loss-offset, regarding taxes levied on a federal level (where there is no tax differential). In this context it is shown that with regard to a federal corporate income tax, on a domestic level companies opt for group taxation if this is advantageous for them in the interests of improved loss-offset (Oestreicher und Koch, 2010). Companies with cross-border activities interpose significantly more often than not pure holding companies in their host countries wherever group taxation is available (Mintz and Weichenrieder, 2010; Oestreicher and Koch, 2012).

The determination of profits under formula apportionment is based on some form of group income resulting from consolidation or combination of income arising at the level of the group companies involved. As a general rule, such consolidation or combination includes offsetting profits against losses earned or suffered by the companies concerned. Besides, the consolidation or combination of income removes all incentives to undertake profit shifting by way of intra-group finance or transfer pricing. Instead, in such a regime the corporate income tax takes the form of separate taxes on the factors included in the allocation formula (Mintz, 1999; McLure, 1980). This implies that where allocation factors relate to company parameters, companies can use this to optimize the distribution of these amounts across the individual tax jurisdictions. This feature influences decisions relating to economic values (allocation ofassets, payroll costs, number of employees and/or sales volume, for example) underlying the allocation formula in a highly complex manner (Gordon and Wilson, 1986). Gérard (2006, 2007) expects the tax-rate sensitivity of investment to increase if the definition of the formula is based predominantly on a factor that is under the control of the multinational. 
In contrast to separate accounting there are few empirical studies on tax plan-ning and the impact of differences in tax rates and formula weights on company decisions under formula apportionment. Existing analyses are based to a large extent on data from the U.S. and Canada (Weiner, 1994; Klassen and Shackelford, 1998; Grubert and Mutti, 2000; Goolsbee and Maydew, 2000; Gupta and Hofmann, 2002; Edmiston, 2002, and Edmiston and Arze del Granado, 2006). Mintz and Smart, 2004 find that taxable income of companies under separate accounting varies with tax rates to a significantly larger extent than taxable income of entities using formula apportionment, which indicates that determining income under separate accounting is subject to profit shifting.

The tax regimes analyzed do not allow the optional application of either separate accounting or formula apportionment for corporate groups to be considered, as would be the case if the CCCTB were to be established. In Canada the option of employing separate accounting or formula apportionment is linked with the choice between a subsidiary and a branch, which should also be influenced by factors other than taxation, whereas in the U.S. states under 'unitary taxation' formula apportionment is mandatory with respect to 'unitary businesses' if the criteria constituting such unitary businesses are met.

In Germany, when a commercial enterprise operates in several different municipalities, the trade income of this enterprise in Germany must be allocated to its parts operating in the municipalities concerned according to a given formula (Riedel, 2010; Büttner, Riedel and Runkel, 2011). For trade-tax purposes, allocation of profits according to a formula is also prescribed for tax groups (Büttner, Riedel and Runkel, 2011). Unlike legally and economically independent entities however, since 2002 the group can opt to fulfill the preconditions of a tax group by concluding a profit and loss-transfer agreement (i.e., to consolidate profits and losses and apply formula apportionment) or, alternatively, to assess the group companies individually (separate accounting). In 2001 a reform of corporate income tax had the effect that the costs associated with non-consolidation for trade tax purposes were increased because loss-offset opportunities were reduced for those firms that were not consolidated. Given the fact that non-consolidation involves an increase of costs, in the scope of a natural experiment for the year 2001 Büttner, Riedel and Runkel, 2011 were able to examine whether multi-jurisdictional entities increase profit-shifting activities under a tax system of consolidation and formula apportionment, if this tax system allows 
individual affiliates to be run as separate entities for tax purposes ('strategic consolidation'). Using company data reported in the trade tax statistics for 1998 and 2001, the authors point out that the varying trade-tax rate among German municipalities exercises a significantly negative influence on the number of consolidated group companies. Hence, Büttner, Riedel and Runkel, 2011 consider the choice between separate accounting and formula apportionment, where possibilities for intra-group loss offset are given also under separate accounting.

\section{A static model of the determination of taxable income}

Due to the complexity of the situations examined, which rules out theoretical analysis using fully fledged models, our experiment consists of four treatments. All situations involve stochastic elements related to the risk of a loss. Due to tax-loss carry forwards, our experiment is based on a dynamic game rather than a simple repetition of one that remains static. An additional complication in carrying out theoretical analysis relates to the manager (rather than owner) compensation in two of the four treatments: in contrast to owners, managers are not accountable for losses.

In this section we present a static model, without consideration of tax-loss carryforwards. We assume that the decision makers are owners and thus accountable for any losses. This implies that we may consider the first-order conditions for the maximization of expected profits without the need to consider any constraints related to loss situations or very low gains. For this static model we deduce first-order conditions for the allocation of production factors and transfer strategies under each tax regime. Solutions for the dynamic game versions will be identified in numerical simulations, in which we make use of the first-order conditions (see Section 4.4 below).

\subsection{Basic assumptions}

The model is based on a fictitious multinational enterprise operating in three countries called I, II and Z. Each country hosts a subsidiary of this multinational enterprise, production sites (called investment objects IO I and IO II) in the countries I and II, and passive operations (called additional investment object Z) in country Z. IO I and IO II produce homogenous goods using $v_{i}$ production factors, $v_{i} \in \mathrm{R}^{+}$, with $i \in\{1,2\}$. For simplicity, we shall not distinguish between labor and capital input, assuming that they are linked. In country $\mathrm{Z}$ the multinational has located passive operations (additional investment object $\mathrm{Z}$ ), which do not produce real goods. It can 
only derive income from financial transactions between itself and IO I or IO II, which can be of interest for tax purposes.

The investment objects in countries 1 and 2 have different profit functions. We assume that each investment object may realize either a gain or a loss, the levels depending on the number of production factors allocated to the respective investment object. In other words, we assume for each investment object a profit function for the case of a positive gain, $F_{i}^{G}\left(v_{i}\right)$ and for a loss, $F_{i}^{V}\left(v_{i}\right)$, each depending on the allocation of the production factors to that investment object. The gain functions have standardized properties, with $F_{i}^{G} / d v_{i}>0$ and $d^{2} F_{i}^{G} / d v_{i}{ }^{2} \leq 0$. The characteristics of the loss functions are the same, but with opposite algebraic signs. We assume that a number of $N$ production factors is available to the multinational enterprise and that these $N$ factors are to be allocated among the two investment objects. Since it thus holds that $v_{2=N}-v_{1}$, we can express each gain or loss function as a function of $v_{1}$. This facilitates the derivation of the first-order conditions for profit maximization shown below. Note that the following analyses are based on the assumption of risk neutrality.

The outcomes are presented based on marginal gains and losses (expected marginal profits) with respect to the number $v_{i}$ of production factors invested in the same country i. We simply denote $F_{i}^{G}, F_{i}^{V}$, and $F_{i}^{G^{\prime}}=d F_{i}^{G} / d v_{i}, F_{i}{ }^{V^{\prime}}=d F_{i} V / d v_{i}$. It holds that $F_{2}^{G \prime}=-\frac{d F_{2}^{G}}{d v_{1}}$ and $F_{2}^{V \prime}=-\frac{d F_{2}^{V}}{d v_{1}}$.

We assume that in each investment object, a gain occurs with the probability p, and a loss with the residual probability $(1-\mathrm{p})$. The multinational enterprise's expected pretax profit, $\prod^{\text {pre-tax }}$, is determined by the sum of expected pre-tax profits in IO I and IO II, $\pi_{1}$ and $\pi_{2}$.

$$
\prod_{p r e-t a x}=\pi_{1}+\pi_{2}=p F_{G}^{1}+(1-p) F_{V}^{1}+p F_{G}^{2}+(1-p) F_{V}^{2}
$$

Maximization of the sum of expected pre-tax profits with respect to the number of production factors in each of the two investment objects would require an allocation of the production factors such that the expected marginal profit is the same in IO I and IO II, i.e., $\pi_{1}{ }^{\prime}=\pi_{2}$ '

Introducing now the matter of taxation, we assume that gains realized in IO I, IO II or shifted to $\mathrm{Z}$ are taxed at a country specific rate $t_{1}, t_{2}$ and $t_{Z}$, respectively. Without loss of generality, it is assumed that $t_{1}<t_{2}$ and $t_{Z}<t_{2}$. Losses do not affect the multina- 
tional's tax burden in the specific period. However, losses can be carried forward, thereby decreasing the tax burden in future periods. As already mentioned above, in the following analysis, we ignore this effect because a fully-fledged dynamic maximization that takes the carrying forward of losses into account would be far too complex to be manageable. We do, however, take account of the possibility to carry forward losses in our numerical simulations.

In the following, we assume that, prior to its factor-allocation decision and prior to the realization of positive or negative profits in the two investment objects, the enterprise can choose between two exclusive tax regimes, separate accounting (Section 3.2) and formula apportionment (Section 3.3). In Section 3.4, we allow for transfer pricing and consider optimal strategies under each tax regime.

\subsection{Separate accounting}

In the case of separate accounting, the profits of IO I, IO II (and Z) are taxed at the country specific rate $t_{1}, t_{2}$ (and $t_{Z}$ ), respectively. Note that since no transfer pricing is included in the analysis at this stage, the profit of the subsidiary located in country $\mathrm{Z}$ is zero.

The expected after-tax profit of the multinational enterprise under separate accounting, $\prod^{\mathrm{SA}}$ results as follows.

$$
\Pi^{\mathrm{SA}}=\mathrm{p} F_{1}^{G}\left(v_{1}\right)\left(1-t_{1}\right)+(1-p) F_{1}^{V}\left(v_{1}\right)+\mathrm{p} F_{2}^{G}\left(v_{1}\right)\left(1-t_{2}\right)+(1-p) F_{2}^{V}\left(v_{1}\right)
$$

Maximizing this expression with respect to the number of production factors in each of the two investment objects leads to the first order condition:

$$
p F_{1}^{G^{\prime}}\left(1-t_{1}\right)+(1-p) F_{1}^{V^{\prime}}=p F_{2}^{G^{\prime}}\left(1-t_{2}\right)+(1-p) F_{2}^{V^{\prime}}
$$

Maximization of the sum of expected after-tax profits under separate accounting with respect to the allocation of production factors in each of the two investment objects requires an allocation such that the expected marginal after-tax profit is the same in IO I and IO II. In general, if we have internal solutions and if we ignore the fact that in the experiment factors can only be allocated in integers, this allocation differs from the optimal allocation pre-tax in that more factors will be allocated to the investment object with the lower tax rate, which is IO I according to our assumptions above. 


\subsection{Formula apportionment}

In the case of formula apportionment the consolidated profits of IO I and IO II are taxed at a combined tax rate. (The passive operations in country $\mathrm{Z}$ are not subject to consolidation. Profits derived in $\mathrm{Z}$ are still taxed at the rate $t_{Z}$ and do not play a role here.) The weighting of local tax rates, $t_{1}$ and $t_{2}$, in the combined tax rate depends on the sum of wages paid in each of the two investment objects. Since we do not explicitly model the input of labor and capital in a production function, we use the sum of the marginal profits of each production factor allocated to an investment object as a proxy for the sum of wages paid in this investment object (under the general assumption that labor is remunerated such that the wage equals the marginal productivity of labor):

$$
L_{i}\left(v_{i}\right)=p \sum_{j=1 . . v_{i}} F_{i}^{G \prime}(j)+(1-p) \sum_{j=1 . . v_{i}} F_{i}^{V \prime}(j)
$$

Based on L1, L2, and t1, t2 the combined tax rate results as

$$
t=t_{1} \frac{L_{1}\left(v_{1}\right)}{L_{1}\left(v_{1}\right)+L_{2}\left(v_{2}\right)}+t_{2} \frac{L_{2}\left(v_{2}\right)}{L_{1}\left(v_{1}\right)+L_{2}\left(v_{2}\right)}
$$

The expected after-tax profit of the multinational enterprise under formula apportionment $\prod^{\mathrm{FA}}$ is as follows:

$$
\begin{aligned}
& \Pi^{\mathrm{FA}}=\mathrm{p}^{2}\left(\mathrm{~F}_{1}^{\mathrm{G}}+\mathrm{F}_{2}^{\mathrm{G}}\right)(1-\mathrm{t})+\mathrm{p}(1-\mathrm{p})\left[\left(\mathrm{F}_{1}^{\mathrm{G}}+\mathrm{F}_{2}^{\mathrm{V}}\right)-\operatorname{Max}\left(0,\left(\mathrm{~F}_{1}^{\mathrm{G}}+\mathrm{F}_{2}^{\mathrm{V}}\right) \mathrm{t}\right)\right] \\
& +\mathrm{p}(1-\mathrm{p})\left[\left(\mathrm{F}_{1}^{\mathrm{V}}+\mathrm{F}_{2}^{\mathrm{G}}\right)-\operatorname{Max}\left(0,\left(\mathrm{~F}_{1}^{\mathrm{V}}+\mathrm{F}_{2}^{\mathrm{V}}\right) \mathrm{t}\right)\right]+(1-p)^{2}\left(\mathrm{~F}_{1}^{\mathrm{V}}+\mathrm{F}_{2}^{\mathrm{V}}\right)
\end{aligned}
$$

Maximizing this expression with respect to the number of production factors in each of the two investment objects leads to a set of four first-order conditions, depending on the gain-loss situation in IO I and IO II:

(1) For $F_{1}^{G} \geq\left|F_{2} V\right|, F_{2}^{G} \geq\left|F_{1} V\right|$ :

$$
\begin{aligned}
& p F_{1}^{G^{\prime}}(1-t)+(1-p) F_{1}^{V^{\prime}}(1-p t)-\left(p F_{1}^{G} t^{\prime}+p F_{1}^{V}\left(t^{\prime}-p t^{\prime}\right)\right. \\
& =p F_{2}^{G^{\prime}}(1-t)+(1-p) F_{2}^{V^{\prime}}(1-p t)-\left(p F_{2}^{G} t^{\prime}+p F_{2}^{V}\left(t^{\prime}-p t^{\prime}\right)\right.
\end{aligned}
$$


(2) For $F_{1}^{G}>\left|F_{2} V\right|, F_{2}^{G}<\left|F_{1} V\right|$ :

$$
\begin{gathered}
p F_{1}^{G^{\prime}}(1-t)+(1-p) F_{1}^{V^{\prime}}-p F_{1}^{G} t^{\prime}= \\
p F_{2}^{G \prime}(1-p t)+(1-p) F_{2}^{V \prime}(1-p t)+p^{2} \mathrm{~F}_{2}^{G} t^{\prime}+\mathrm{pF}_{2}^{V}\left(t^{\prime}-p t^{\prime}\right)
\end{gathered}
$$

(3) For $F_{1}^{G}<\left|F_{2} V\right|, F_{2} G>\left|F_{1} V\right|$ :

$$
\begin{aligned}
p F_{1}^{G \prime}(1-p t)+ & (1-p) F_{1}^{V^{\prime}}(1-p t)-\left(p^{2} F_{1}^{G} t^{\prime}+p F_{1}^{V}\left(t^{\prime}-p t^{\prime}\right)\right) \\
& =p F_{2}^{G^{\prime}}(1-t)+(1-p) F_{2}^{V^{\prime}}-\left(\mathrm{pF}_{2}^{\mathrm{G}}\left(\mathrm{p} t^{\prime}+t^{\prime}\right)-\mathrm{p}^{2} \mathrm{~F}_{2}^{V} t^{\prime}\right)
\end{aligned}
$$

(4) For $F_{1}^{G}<\left|F_{2} V\right|, F_{2}^{G}<\left|F_{1} V\right|$ :

$$
p F_{1}^{G \prime}(1-p t)+(1-p) F_{1}^{V \prime}-p^{2} \mathrm{~F}_{1}^{G} t^{\prime}=p F_{2}^{G^{\prime}}(1-p t)+(1-p) F_{2}^{V^{\prime}}-p^{2} \mathrm{~F}_{1}^{G} t^{\prime}
$$

Since $F_{i}^{G}$ and $F_{i} V$ are functions of $v_{i}$, to satisfy the respective first-order condition the range of $v_{i}$ that determines whether we are in case (1), (2), (3) or (4) needs to be consistent with the range of $v_{i}$ of the respective case. This will lead to a valid solution within one of the four cases.

\subsection{Including transfer-pricing strategies}

Under each of the tax two regimes, separate accounting or formula apportionment, the multinational enterprise has opportunities to reduce the tax burden by way transfer pricing.

\subsubsection{Separate accounting}

In the case of separate accounting the multinational enterprise has two ways to reduce the corporate tax burden. These possibilities may be combined. The first possibility allows the multinational enterprise to shift pre-tax income from the highly taxed investment object IO II to the lower taxed investment object IO I. This shift of income is called $T_{1}$. The second possibility allows the multinational enterprise to shift pre-tax income from IO II to the lower taxed additional investment object located in country $Z$. This shift of income is called $T_{Z}$ and is taxed at the rate $t_{Z}$. 
However, the use of this accounting leeway is not necessarily free of charge. It may be subject to an audit by tax authorities in country II. If a profit shift between IO I and IO II (or Z) is detected by the tax authorities, it incurs a subsequent tax payment. The amount of the additional tax payment is assumed to be the shifted amount from IO II to IO I or from IO II to the additional investment object ( $Z$ ), multiplied by the tax rate differential between IO II and IO I ( or Z) and multiplied by a penalty factor $k$ $(\mathrm{k}>1)$. The probability of an additional payment being charged likewise depends on the shifted amount, multiplied by a factor $l_{1}$ or $l_{Z}\left(11<1, l_{z}<1\right)$, respectively.

The overall expected cost of profit shifts under separate accounting, $K_{1}$, is:

$$
K_{1}=\left(t_{2}-t_{1}\right) k l_{1} T_{1}^{2}+\left(t_{2}-t_{Z}\right) k l_{Z} T_{Z}^{2}
$$

The expected after tax profit under separate accounting and under consideration of profit shifts is as follows.

$$
\begin{aligned}
\Pi^{\mathrm{SA}, \mathrm{T} 1, \mathrm{TZ}}=\mathrm{p}( & \left.\left(F_{1}^{G}+T_{1}\right)\left(1-t_{1}\right)+\left(F_{2}^{G}-T_{1}-T_{Z}\right)\left(1-t_{2}\right)\right) \\
& +(1-p)\left(\left(F_{1}^{V}+T_{1}-\operatorname{Max}\left(0, F_{1}^{V}+T_{1}\right) t_{1}+\left(F_{2}^{V}-T_{1}-T_{Z}\right)\right)\right. \\
& \left.+T_{Z}\left(1-t_{Z}\right)\right)-\left(\left(t_{2}-t_{1}\right) k l_{1} T_{1}{ }^{2}+\left(t_{2}-t_{Z}\right) k l_{Z} T_{Z}{ }^{2}\right)
\end{aligned}
$$

The first-order condition for maximizing the multinational enterprise's expected profit with respect to the production factors in each of the investment objects requires the consideration of case distinction. These relate to the size of the transfers relative to the respective potential loss of the object to which the profit has been shifted. In the case of a relatively small transfer, the optimal factor allocation is the same as without profit shifts. Otherwise, more factors are to be allocated to IO II. The firstorder conditions with respect to the amount of transfer from IO II to IO I are also dependent on the relationship between the amount transferred and the magnitude of potential loss:

- $\quad F_{1}^{V}+T_{1} \geq 0$ :

$$
p t_{2}-t_{1}=2\left(t_{2}-t_{1}\right) k l_{1} T_{1}
$$

- $F_{1}^{V}+T_{1}<0$ :

$$
p\left(t_{2}-t_{1}\right)=2\left(t_{2}-t_{1}\right) k l_{1} T_{1}
$$


The first-order condition with respect to the transfer from IO II to the additional investment object is:

$$
p t_{2}-t_{z}=2\left(t_{2}-t_{Z}\right) k l_{Z} T_{Z}
$$

The optimal amount of profit to be shifted to IO I or to the additional investment object $\mathrm{Z}$ is determined such that the expected marginal tax reduction equals the expected marginal cost of a profit shift.

\subsubsection{Formula apportionment}

In the case of formula apportionment the multinational enterprise also has an opportunity to use intra-firm transactions to reduce the corporate tax burden. It can shift parts of the aggregated pre-tax profit to the lower taxed additional investment object located in country $Z$. This shift of income is called $T_{Z}$. It is taxed at the rate $t_{Z}$.

Again, the use of accounting leeway is not free of charge. The amount of an additional tax payment - in the event that use of accounting leeway between IO II and the additional investment object is detected - depends on the shifted amount. The shifted amount is multiplied by the tax rate differential between the combined tax rate of the tax group and the additional investment object and the penalty factor $k(k>1)$. The probability of detection depends on the shifted amount, multiplied by the factor $l_{Z}\left(l_{Z}<1\right)$. The expected cost of a profit shift under formula apportionment is:

$$
K_{2}=\left(€-t_{Z}\right) k l_{Z} T_{Z}^{2}
$$

Under consideration of penalties, the expected after-tax profit of formula apportionment can be set out as follows:

$$
\begin{aligned}
\prod^{\mathrm{FA}, \mathrm{TZ}}=p^{2}\left(F_{1}^{G}\right. & \left.+F_{2}^{G}-T_{Z}\right)(1-t) \\
& +p(1-p)\left[\left(F_{1}^{G}+F_{2}^{V}-T_{Z}\right)-\operatorname{Max}\left(0, F_{1}^{G}+F_{2}^{V}-T_{Z}\right) t\right] \\
& +\mathrm{p}(1-p)\left[\left(F_{1}^{V}+F_{2}^{G}-T_{Z}\right)-\operatorname{Max}\left(0, F_{1}^{V}+F_{2}^{V}-T_{Z}\right) t\right] \\
& +(1-p)^{2}\left(F_{1}^{V}+F_{2}^{V}-T_{Z}\right)+T_{Z}\left(1-t_{Z}\right)-\left(\left(t-t_{Z}\right) k l_{Z} T_{Z}{ }^{2}\right)
\end{aligned}
$$

This leads to the following first-order conditions for maximizing the multinational enterprise's profit with respect to the transfer to the additional investment object in 
the case of formula apportionment. The result depends on the amount of the transfer relative to the amount of potential losses and the tax rate differential between the group and the additional investment object $Z$.

(1) For $F_{1}^{G} \geq\left|F_{2} V\right|, F_{2}^{G} \geq\left|F_{1} V\right|$ :

$$
\mathrm{p}^{2} \mathrm{t}+2 \mathrm{p}(1-\mathrm{p}) \mathrm{t}-\mathrm{t}_{\mathrm{Z}}=2 \mathrm{l}_{\mathrm{z}}\left(\mathrm{t}-\mathrm{t}_{\mathrm{Z}}\right) \mathrm{kT}_{\mathrm{Z}}
$$

(2) For $F_{1}^{G}>\left|F_{2}^{V}\right|, F_{2}^{G}<\left|F_{1}^{V}\right|$ and $F_{1}^{G}<\left|F_{2}^{V}\right|, F_{2}^{G}>\left|F_{1}^{V}\right|$ :

$$
\mathrm{p}^{2} \mathrm{t}+\mathrm{p}(1-\mathrm{p}) \mathrm{t}-\mathrm{t}_{\mathrm{z}}=2 \mathrm{l}_{\mathrm{Z}}\left(\mathrm{t}-\mathrm{t}_{\mathrm{Z}}\right) \mathrm{kT}_{\mathrm{Z}}
$$

(3) For $F_{1}^{G}<\left|F_{2} V\right|, F_{2}^{G}<\left|F_{1} V\right|$ :

$$
\mathrm{p}^{2} \mathrm{t}-\mathrm{t}_{\mathrm{Z}}=2 \mathrm{l}_{\mathrm{Z}}\left(\mathrm{t}-\mathrm{t}_{\mathrm{Z}}\right) \mathrm{kT}_{\mathrm{Z}}
$$

Again the optimal amount of a profit shift is determined such that the marginal tax reduction equals the expected marginal cost.

\section{Experimental design}

\subsection{Basics}

Based on the model presented above, we conduct a laboratory experiment to tackle the research questions, (1) to what extent corporations would be inclined to take up a consolidation option under various conditions, and (2) how this would impact the location of investment and transfer-pricing activities. Over the course of $\mathbf{1 5}$ periods, the participant in this experiment will make individual decisions as the responsible representative of a group of companies. The experiment consists of a 2-by-2 design, varying the tax rate differential and the remuneration of the decision maker. Each treatment involves the choice between separate accounting and formula apportionment, and the possibility of using tax planning strategies associated with these tax regimes. These strategies include the allocation of production factors and the transfer of profits from IO II to IO I (under separate accounting), and the transfer of profits (from IO II or the tax group) to the additional investment object $\mathrm{Z}$.

To present the investment decisions in a manner comparable to the actual situation of a multijurisdictional enterprise, we need to base our laboratory experiment on realistic input data. For this reason our input factors are linked to (German) company data (the proportion of profits made and losses incurred by the subsidiaries of a mul- 
tijurisdictional enterprise including the relevant probabilities associated with these profits or losses) making use of the database AMADEUS (updates 125 and 172).

AMADEUS is a comprehensive, pan-European database containing financial information on some nine million public and private companies in 38 European countries. It is made available by the private database provider Bureau van Dijk. The database contains standardized (consolidated and unconsolidated) annual accounts, financial ratios, activities, and ownership information on the companies included. AMADEUS data allows us to derive the proportion of profits made and losses incurred by the subsidiaries of a multijurisdictional enterprise (on average), providing us with a basis for determining the probability of companies making profits or incurring losses. In order to do so, in a first step (1) the 'average profit of all companies observed', and (2) the 'average profit of all profitable companies' and the 'average losses of all companies that incurred losses' were calculated. Based on the results of these calculations, in a second step, scaling factors for the profits and losses incurred by the companies are derived as follows.

$$
\begin{gathered}
\text { Profit }=\frac{\text { Average profit of all profitable companies }}{\text { Average profit all companies observed }} \\
\text { Loss }=\frac{\text { Average loss of all companies that incurred losses }}{\text { Average profit all companies observed }}
\end{gathered}
$$

The probability $p$ of companies making profits is derived by dividing the proportion of German companies reporting profits by the total number of German corporate enterprises. 4 Conversely, the probability of companies incurring losses is $1-p$. According to our data, this latter probability fluctuates around a value of 20 percent, a probability of zero percent being close to zero. Against this background, we assume a probability $1-p$ of 30 per cent within this study.

We take account of a minimal period of commitment of five years with respect to the application of the formula apportionment tax regime. Although the proposed CCCTB does not require such period of commitment the provisions regarding 'entering and leaving the group' (Chapter X, in particular Articles 61, and 68 of the proposed СCCTB directive), and 'business reorganization' (Chapter XI, in particular Article 70.2 of the proposed CCCTB directive) suggests that such duration is taken into ac-

\footnotetext{
4 According to the AMADEUS database the ratio of loss-making and profit-making corporate enterprises is one to four.
} 
count in order for a multinational enterprise to make full use of potential tax advantages resulting from a possible allocation of production factors to low-tax countries. By the same token, German tax law also provides for a minimum commitment period of five years (Sec. 14 CIT).

The use of tax planning strategies is not necessarily free of charge. They may be subject to an audit by the tax authorities. If a profit shift is detected by the tax authorities, an additional tax payment results. We assume that the probability of profit shifting being detected is linear in the shifted amount. For profits shifted between IO II and IO I a probability of 0.00002 is assumed. Profits shifted to the additional investment object $\mathrm{Z}$ is taken into account with a probability of 0.0001.5 As far as penalty payments are concerned reference is made to tax practice in Germany, leading us to a penalty factor $k$ of 1.25 (Section 3.4 above, equations 8 and 12). ${ }^{6}$ In terms of expected values, if profit shifting is disregarded, the benefits of an immediate intragroup loss-offset render formula apportionment the predominant element in multinational enterprises' choice of tax regime. However, since several requirements need to be fulfilled (e.g., formal requirements associated with the application process, legal requirements, or additional tax burden resulting from consolidating profits and losses) the formation of a tax group is by no means free of cost. In the experiment we impose a onece only cost for the first-time application of formula apportionment. We determine the cost level assuming this cost to equal the expected benefit resulting from the application of formula apportionment over a period of three years. This means that the expenses associated with the introduction of formula apportionment are amortized after 60 per cent of the commitment period has elapsed.

\subsection{Treatments}

We use the tax-rate differential as a treatment variable and consider differentials of five percent and 15 percent. These tax-rate differentials are designed such that positive returns in IO I and $\mathrm{Z}$ are always subject to a tax burden of 15 percent whereas in the case of a high tax-rate differential (15 percent) positive returns of IO II are taxed at a rate of 30 percent and in the case of a low tax-rate differential (five percent) they are subject to a tax-rate of 20 percent. These differences in corporate tax rates are

\footnotetext{
${ }^{5}$ I.e. the probability of detection increases by 0.1 per cent or 1 per cent, respectively, with each 100 units of profits transferred.

${ }^{6}$ According to Sec. 238 German tax code tax payments are charged at a rate of 0.5 percent. Interest is payable starting fifteen months after the end of the relevant tax year. Considering an average tax-audit period of five years (Deloitte 2011), we arrive at a penalty of approximately 25 percent of saved taxes.
} 
based on the range of possible tax rates applicable to multinational enterprises within the European Union.

The participants in the experiment are remunerated based on the profit made by way of investing in IO I, IO II, and Z. We use remuneration as a treatment variable and distinguish between two scenarios: the decision maker is either owner or manager. We take into account the fact that managers are commonly granted bonus payments only if a pre-determined level of profit is realized. Therefore, in the manager scenario, their remuneration relates to the return on investment exceeding a predefined (minimum) profit after tax $(16,000$ if the tax-rate of IO II is 30 percent and 18,000 if the tax-rate of IO II is 20 percent) or is zero otherwise. The conversion factor from profit to remuneration is determined such that the expected distribution of the remuneration is similar in all treatments.

Note that our theoretical considerations in Section 3 are based on the assumption of a multinational enterprise seeking to maximize expected profits after tax and bearing the risk of the actual occurrence of a loss. For companies managed by employees, it cannot be excluded that different objectives come into play. It is not uncommon for managers to receive remuneration that is geared to profit. However, it is unusual for the remuneration scheme to make employed managers liable for losses incurred by the company (see e.g., Andreas, Rapp, Wolff, 2011). Taking into consideration the risk of a potential loss may reflect the situation of a transparent entity managed by its owners. Therefore, in the owner scenario, the design of our experiment is based on the assumption that the participants in the experiment earn remuneration linked to the (positive or negative) profit made from investing in IO I, IO II, and Z.

Table 1 presents the parameters of the four treatments.

Table 1: Treatment design

\begin{tabular}{l|c|c|c|c} 
& Owner 15 & Owner 5 & Manager 15 & Manager 5 \\
\hline $\begin{array}{l}\text { Probability of incurring a } \\
\text { loss (in percent) }\end{array}$ & 30 & 30 & 30 & 30 \\
$\begin{array}{l}\text { Remuneration } \\
\text { Tax rate differential }\end{array}$ & Owner & Owner & Manager & Manager \\
\hline \hline
\end{tabular}




\subsection{Decision-making process}

After presenting the instructions (see a translated version of the "instructions manual" in the Appendix A to this paper) to the participants and clarifying any questions, participants were seated at a computer in the Göttingen Laboratory of Behavioral Economics and asked to make their individual decisions over the course of fifteen periods. In each period, the participants had to decide in a first step whether they wished to opt for separate taxation of the investment objects or group taxation. Group taxation runs over a sequence of five years. This means that if a participant had opted for group taxation the choice-of-tax-regime step was unavailable in the four following periods. After five periods, separate accounting again became an option.

In the second step, depending on their individual choice of tax regime, the participants were asked to make an investment decision (allocation of production factors) and decide whether, and if so, how they wished to make use of accounting leeway.

Allocation of production factors: participants have to allocate $N=15$ available production factors among IO I and IO II. A minimum of one production factor has to be invested in each of the two alternative investments objects. The returns of IO I and IO II differ. For IO II we assume a production function of $F_{2}^{G}\left(v_{2}\right)=3.015 * v_{2}$, where $v_{2}$ is the number of production factors invested in IO II. This production function is characterized by constant marginal returns $\left(F_{2}^{G^{\prime \prime}}\left(v_{2}\right)=0\right)$. For IO I we assume a production function of $F_{1}^{G}\left(v_{1}\right)=3.120 * v_{1}-29 * v_{1}^{2}$. This production function is characterized by decreasing marginal returns $\left(F_{1}^{G^{\prime \prime}}\left(v_{1}\right)=-58\right)$.

Based on the values of Profit and Loss defined in equations 15.1 and 15.2 above, we may link profits and losses of the investment objects (IO I, and IO II) by a factor of approximately $-\frac{2}{3}\left(\right.$ e.g. $\left.F_{1}^{V}\left(v_{1}\right)=-\frac{2}{3} * F_{1}^{G}\left(v_{1}\right)\right)$.

Profits and losses depending on the allocation of production factors are presented in Table 2. A comparable table was included in the written experiment instructions (which were also read aloud to the participants) and available for view on the computer screen. 
Table 2: Returns of IO I and IO II

\begin{tabular}{|ccc|ccc|}
\hline $\begin{array}{c}\text { Number } \\
\text { of factors }\end{array}$ & $\begin{array}{c}\text { IO I } \\
\text { Profit } \\
(\mathrm{p}=70 \%)\end{array}$ & $\begin{array}{c}\text { Loss } \\
(\mathrm{p}=30 \%)\end{array}$ & $\begin{array}{c}\text { Number } \\
\text { of factors }\end{array}$ & $\begin{array}{c}\text { IO II } \\
\text { Profit } \\
(\mathrm{p}=70 \%)\end{array}$ & $\begin{array}{c}\text { Loss } \\
(\mathrm{p}=30 \%)\end{array}$ \\
\hline$(1)$ & $(2)$ & $(3)$ & $(4)$ & $(5)$ & $(6)$ \\
\hline 1 & 3,091 & $-2,061$ & 14 & 42,210 & $-28,140$ \\
2 & 6,124 & $-4,084$ & 13 & 39,195 & $-26,130$ \\
3 & 9,099 & $-6,069$ & 12 & 36,180 & $-24,120$ \\
4 & 12,016 & $-8,016$ & 11 & 33,165 & $-22,110$ \\
5 & 14,875 & $-9,925$ & 10 & 30,150 & $-20,100$ \\
6 & 17,676 & $-11,796$ & 9 & 27,135 & $-18,090$ \\
7 & 20,419 & $-13,629$ & 8 & 24,120 & $-16,080$ \\
8 & 23,104 & $-15,424$ & 7 & 21,105 & $-14,070$ \\
9 & 25,731 & $-17,181$ & 6 & 18,090 & $-12,060$ \\
10 & 28,300 & $-18,900$ & 5 & 15,075 & $-10,050$ \\
11 & 30,811 & $-20,581$ & 4 & 12,060 & $-8,040$ \\
12 & 33,264 & $-22,224$ & 3 & 9,045 & $-6,030$ \\
13 & 35,659 & $-23,829$ & 2 & 6,030 & $-4,020$ \\
14 & 37,996 & $-25,396$ & 1 & 3,015 & $-2,010$ \\
\hline \hline
\end{tabular}

Profit shifts: Where the participants opted for separate taxation of the investment objects, they had to decide on the profit amount they wished to shift from IO II to IO I, and on the profit amount they wished to shift from IO II to the additional investment object. Where the participants opted for formula apportionment, they were asked to decide on the profit amount they wished to shift from "the group" (IO I and IO II) to the additional investment object.

The use of tax-planning strategies can be detected by tax-authorities. Both the probability of being subject to a tax audit and the amount of additional payment depend on the amount of profits shifted. The amounts of profit shifts related to selected probabilities of being subject to a tax audit (in steps of five percent between five and 100 percent) and the corresponding penalty payments are included in the instructions manual and are also available for view on the computer screen. Table 3 presents these numbers for profit shifts to IO I in the case of a tax-rate differential of 15 percent.

Any profit shift was limited by the potential profit in IO II, or, if group taxation was used, the sum of potential profits in both IOs, given the allocation of production factors in the first step. 
Table 3: Probabilities of detection and penalty payments for profit shifts to IO I

\begin{tabular}{|c|c|c|}
\hline Shifted amount & $\begin{array}{l}\text { Probability of additional } \\
\text { payment } \\
\text { (percent) }\end{array}$ & $\begin{array}{l}\text { Amount of additional } \\
\text { payment }\end{array}$ \\
\hline (1) & (2) & (3) \\
\hline & $(1) \times 0,00002$ & (1) $\times 0.15 \times 1,25$ \\
\hline O & o & O \\
\hline 2,500 & 5 & 469 \\
\hline 5,000 & 10 & 938 \\
\hline 7,500 & 15 & 1,406 \\
\hline 10,000 & 20 & 1,875 \\
\hline 12,500 & 25 & 2,344 \\
\hline 15,000 & 30 & 2,813 \\
\hline 17,500 & 35 & 3,281 \\
\hline 20,000 & 40 & 3,750 \\
\hline 22,500 & 45 & 4,219 \\
\hline 25,000 & 50 & 4,688 \\
\hline 27,500 & 55 & 5,156 \\
\hline 30,000 & 60 & 5,625 \\
\hline 32,500 & 65 & 6,094 \\
\hline 35,000 & 70 & 6,563 \\
\hline 37,500 & 75 & 7,031 \\
\hline 40,000 & 80 & 7,500 \\
\hline 42,500 & 85 & 7,969 \\
\hline 45,000 & 90 & 8,438 \\
\hline 47,500 & 95 & 8,906 \\
\hline 50.000 & 100 & 9,375 \\
\hline
\end{tabular}

Having entered an investment decision, participants were given the opportunity to obtain a summary and consequences of their entries by clicking the button "show consequences". For the four possible profit-and-loss situations in IO I and IO II (profit-profit, profit-loss, loss-profit, and loss-loss), depending on their factor allocation, participants could see the resulting pre-tax results, the amount(s) of profit shifted and the corresponding probability and amount of an additional tax payment. Participants were allowed to revise their investment decisions until they pressed the "ENTER" button. By pressing the button "See results of previous rounds" they had the opportunity to view their profits and losses accrued in the previous periods.

At the end of each period, participants were informed of their individual profit-loss situation, any detection of profit shifted, and related additional payment to tax authorities, their net result, and remuneration of the period just completed (in Eurocent), and a detailed calculation of net result. Loss carry-forwards in an investment object are utilized if a profit is accrued in a current period. The amount of losses to be carried forward was shown on screen at all times. 


\subsection{Deriving theoretical after-tax results}

Based on the marginal conditions derived in Section 3 above, the after-tax results in each of the four treatments were derived by simulating, the decision-making process 10,000 times in the course of the 15-period experiment.7 A simulation approach was used because due to the dynamic experimental design (caused by the consideration of losses carried forward) and the large number of maximum conditions to be observed. The simulation was carried out in such a way that under consideration of losses carried forward and optimal use of tax planning strategies, the investment option was selected regarding the highest expected return in each of the fifteen periods. ${ }^{8}$ The results are presented in Table 4.

Table 4: Simulation results for optimal behavior in the experiment

\begin{tabular}{|c|c|c|c|c|}
\hline & Owner 15 & Owner 5 & Manager 15 & Manager 5 \\
\hline $\begin{array}{l}\text { Pre-tax factor allocation } \\
\text { (IO I/IO II) }\end{array}$ & $2 / 13$ & $2 / 13$ & $2 / 13$ & $2 / 13$ \\
\hline Expected pre-tax return & 22,659 & 22,659 & 22,659 & 22,659 \\
\hline $\begin{array}{l}\text { Optimal after-tax factor } \\
\text { allocation (SA, IO II) }\end{array}$ & $7 \cdot 35$ & 8.82 & 3.78 & 14 \\
\hline $\begin{array}{l}\text { Optimal expected after-tax } \\
\text { return (SA) }\end{array}$ & 18,517 & 18,596 & 13,497 & 11,841 \\
\hline $\begin{array}{l}\text { Optimal amounts of profit } \\
\text { shifted (IO II to IO I) }\end{array}$ & 10,670 & 10,623 & 2,107 & 29 \\
\hline $\begin{array}{l}\text { Optimal amounts of profit } \\
\text { shifted (IO II to additional } \\
\text { object) }\end{array}$ & 1,430 & o & 1,290 & $\mathrm{o}$ \\
\hline $\begin{array}{l}\text { Optimal after-tax factor } \\
\text { allocation (FA, IO II) }\end{array}$ & 6.58 & 9.22 & 5.21 & 14 \\
\hline $\begin{array}{l}\text { Optimal expected after-tax } \\
\text { return (FA) }\end{array}$ & 17,295 & 18,306 & 13,854 & 13,380 \\
\hline $\begin{array}{l}\text { Optimal amounts of profit } \\
\text { shifted (tax group to addi- } \\
\text { tional object) }\end{array}$ & 621 & o & 590 & o \\
\hline
\end{tabular}

\footnotetext{
7 We use Microsoft Visual Basic Application to simulate the optimal behavior.

${ }^{8}$ In principle, the optimal profit shift is derived using the first-order conditions presented in the theoretical model described above. In the case that the model gives rise to negative expected profits, the optimal profit shift is assumed to be zero. If under separate accounting this profit shift exceeds the upper limit of profit earned in IO II less losses carried forward, the value of profits being shifted is reduced to the upper limit. If the loss carry forward of IO II exceeds the profit of IO II, the profit shift is reduced to zero. Under formula apportionment the limitation of profit shifts to the additional investment object is done in the same way as under separate accounting, with the exception that profits and losses being carried forward are aggregated on group level.
} 


\subsection{Hypotheses}

On the basis of our simulation results presented in Table 4 we derive the following four hypotheses. For owners, separate accounting results in an optimal expected after-tax return of 18,517 and 18,596 , whereas under formula apportionment the optimal after-tax return is 17,295 (Owner 15) and 18,306 (Owner 5), respectively. A comparable result can be observed for managers: separate accounting results in an optimal expected after-tax return of 13,497 and 11,841, whereas under formula apportionment the optimal after-tax return is 13,854 and 13,380 for Manager 15 and Manager 5 , respectively. Hence, in the presence of uncertain returns on investment, in comparison to formula apportionment, separate accounting may be expected to be the preferred institutional regime for owners, whereas from the manager perspective formula apportionment indicates higher returns after tax. However, the differences are small and not statistically significant. ${ }^{9}$ These results lead us to the following hypothesis.

Hypothesis 1: Independently of the tax-rate differential, owners show a slight preference for separate accounting, where managers show a slight preference for formula apportionment.

Starting with an optimal pre-tax factor allocation of 13 out of 15 units to IO II in all four treatments, under separate accounting our model calculates an optimal after-tax factor allocation for Owner 15, Owner 5, Manager 15, and Manager 5 of 7.35, 8.82, 3.78 , and 14 to IO II, whereas in the case of formula apportionment an allocation to IO II of $6.58,9.22,5.21$, and 14 results. Where the tax rate differential is low (Owner 5 and Manager 5), allocating a higher number of production factors to IO II is beneficial; this holds all the more if decisions are made by managers who receive a fixed income plus a performance bonus but do not participate in a loss. Under formula apportionment, generally higher proportions of investments in IO II are required. This gives rise to Hypothesis 2.

Hypothesis 2: Depending on the tax regime, the tax-rate differential has an impact on the investments made. Where the tax-rate differential is low, investment in IO II (subject to comparatively higher tax) is high and thus investment in IO I is comparatively low. This holds for managers and owners. Independently of the tax regime,

\footnotetext{
9 Statistical tests are based on random draws of all simulation runs.
} 
in the case of low tax-rate differential, managers will invest the maximum number of production factors in IOII (Manager 5 ).

As far as the amounts of profit shifted to IO I (separate accounting) are concerned, Table 2 indicates the optimal amount shifted is 10,670 for Owner 15 and 10,623 for Owner 5, whereas the corresponding values are 2,107 and 29 for Manager 15 and Manager 5. Thus, under the present circumstances, the optimal amount of profits shifted to IO I differs between owners and managers: managers shift less than owners. Moreover, the shifted amount is expected to be (slightly) higher where the tax rate differential is high. This leads us to Hypothesis 3 :

Hypothesis 3: The amount of profits shifted between group companies is (a) positively correlated with the tax-rate differential and (b) depends on the remuneration of the decision makers. Owners will shift higher amounts between group companies than managers.

Under separate accounting shifting profits to an additional project is countered by a higher risk of retrospective tax payments then shifting profits to IO I. Hence, profit shifting to an additional object appears to be beneficial only if the tax rate differential is sufficiently large: Table 2 shows that for owners the optimal amount is 1,430 and o (Owner 15, Owner 5), whereas the corresponding values are 1,290 and o for managers (Manager 15, Manager 5). Since formula apportionment is characterized by a mixed tax rate, the relevant tax rate differential is larger under separate accounting than under formula apportionment. As a consequence, the optimal amounts of profit shifted to an additional project fall below the values under separate accounting $(621,0$, 590, and o). These findings lead to Hypothesis 4.

Hypothesis 4: The amount of profits shifted to an additional investment object is positively correlated with the tax rate differential. Furthermore, owners will shift higher amounts than managers.

\section{Results}

Our results are based on computerized experiments conducted at the Göttingen Laboratory of Behavioural Economics (GLOBE). The experiment was programmed and conducted with the experiment software z-Tree (Fischbacher, 2007). A total of 83 
students, 23, 18, 20 and 22 students in treatments Owner 15, Owner 5, Manager 15 and Manager 5, respectively, most of whom attend programs in business administration and business economics, participated in our experiments. Out of the 83 participants, 24 are female and 59 male. They were randomly selected out of a pool of students who had signed up for potential participation in experiments (upon invitation). The student participants earned between 11.00 Euros and 22.10 Euros, the average being 17.71 Euros.

\subsection{Econometric setting}

The analyses of the choice of tax regime (Hypothesis 1), the allocation of production factors (Hypothesis 2), and amount of profit shifed (Hypotheses 3 and 4) are based on three econometric models.

Regression model 1: Since the choice of tax regime (Hypothesis 1) is binary it is analysed by way of probit regression including cluster robust standard errors relating to single individual participants. We use cluster robust standard errors because our dataset includes several observations for each individual. It can be expected that standard errors are correlated on an individual basis. ${ }^{10}$

Regression model 2: The allocation of production factors (Hypothesis 2) is investigated by way of a zero-truncated negative binomial regression model. Again, cluster robust standard errors are used. A zero truncated regression model is appropriate because participants are free to allocate between one and fourteen countable production factors to IO I or IO II. We used a negative binomial model instead of the regular poisson model because a test of equidispersion rejects the 'null' hypothesis at a one-percent level. ${ }^{11}$

Regression model 3: The econometric examination of profits shifted to IO I (Hypothesis 3) or Z (Hypothesis 4), respectively, is based on a linear panel data model. We employ the natural logarithm of profit shifts in order to reduce the influence of outliers. Again, cluster robust standard errors are used in respect of each individual.

Typically, fixed-effect models are applied to exclude unobservable time invariant individual effects. In our study the use of a fixed effects model is not applicable

\footnotetext{
${ }^{10}$ The Wooldridge test (Wooldridge, 2010) for autocorrelation indicates the existence of autocorrelation at a ten-percent level.

${ }^{11}$ The existence of overdispersion is tested in an analogous way, following Cameron and Trivedi, 2010.
} 
because in this case our time invariant treatment variables (remuneration and tax rate differential) would be omitted. Because of this we use a random effects model.

\section{Table 5: Description of independent variables}

\begin{tabular}{|c|c|c|}
\hline Variable & Description & Explanatory statement \\
\hline FA & $\mathrm{O}=\mathrm{SA} / 1=\mathrm{FA}$ & $\begin{array}{l}\text { Selected tax regime might influence the amounts of } \\
\text { profits shifted or allocation of production factors }\end{array}$ \\
\hline Transfer to IO I & $\begin{array}{l}\text { Amount shifted to IO I } \\
\text { scaled in units of } 1,000\end{array}$ & $\begin{array}{l}\text { Volume of profit shifting activities to IO I might have an } \\
\text { effect on the allocation of production factors or profit } \\
\text { shiftings to } Z\end{array}$ \\
\hline Transfer to $\mathrm{Z}$ & $\begin{array}{l}\text { Amount shifted to Z scaled } \\
\text { in units of } 1,000\end{array}$ & $\begin{array}{l}\text { Volume of profit shifting activities to } \mathrm{Z} \text { might have an } \\
\text { effect on the allocation of production factors or profit } \\
\text { shiftings to IO I }\end{array}$ \\
\hline Investment in IO II & $\begin{array}{l}\text { Production factors } \\
\text { allocated at IO II }\end{array}$ & $\begin{array}{l}\text { Amount invested in IO II might influence profit shifting } \\
\text { activities to IO I and / or Z }\end{array}$ \\
\hline $\begin{array}{l}\text { LCF at IO I, IO II or } \\
\text { group level }\end{array}$ & $\begin{array}{l}\text { Amount of losses carried } \\
\text { forward at the level of IOI, } \\
\text { IO II or scaled in units of } \\
10,000\end{array}$ & $\begin{array}{l}\text { Existing loss carry-forwards might prevent a switch in } \\
\text { tax regime, reduce amount of profit shifting or change } \\
\text { the allocation of production factors to reduce loss carry } \\
\text { forwards }\end{array}$ \\
\hline TD15 & $\begin{array}{l}\text { O = Tax-rate differential of } \\
5 \% / 1=\text { Tax-rate } \\
\text { differential of } 15 \%\end{array}$ & Treatment variable \\
\hline Time & Decision making time & $\begin{array}{l}\text { Longer time of investment represents more detailed tax } \\
\text { planning and therefore influences decision making } \\
\text { process }\end{array}$ \\
\hline Period & 1 to 15 & $\begin{array}{l}\text { Control for time effects for example more conservative } \\
\text { decisions in later periods }\end{array}$ \\
\hline Manager & $\mathrm{O}=$ Owner $/ 1=$ Manager & Treatment variable \\
\hline $\begin{array}{l}\text { Detection of transfer(s) } \\
\text { in prior period }\end{array}$ & $\begin{array}{l}0=\text { no detection in prior } \\
\text { period } / 1=\text { detection in } \\
\text { prior period }\end{array}$ & $\begin{array}{l}\text { Regarding prior research (Mittone, 2006) detection of } \\
\text { tax planning in prior period influences tax planning in } \\
\text { the current period }\end{array}$ \\
\hline Master & $\mathrm{O}=$ Bachelor $1=$ Master & Control for different levels of experience \\
\hline Gender & $\mathrm{O}=$ Female $/ 1=$ Male & Control for gender differences \\
\hline Business experience & $0=$ No $/ 1=$ Yes & Control for different levels of experience \\
\hline Tax return prepared & $\mathrm{O}=\mathrm{No} / 1=\mathrm{Yes}$ & Control for different levels of experience \\
\hline Risk level & $\mathrm{o}=$ Low up to $7=$ High & Control for self-estimated risk-taking \\
\hline Impulsivity & $\mathrm{O}=$ Low up to $7=$ High & $\begin{array}{l}\text { Because of a high complex setting, this variable should } \\
\text { control for spontaneous decisions }\end{array}$ \\
\hline Age & Age of participant & Control for different levels of experience \\
\hline $\begin{array}{l}\text { Program of study } \\
\text { (business } \\
\text { administration, } \\
\text { economics, other) }\end{array}$ & $\begin{array}{l}\text { Dummy variables equal } 1 \text { if } \\
\text { participants take part in } \\
\text { programs mentioned }\end{array}$ & $\begin{array}{l}\text { Control for different levels of experience in the case of } \\
\text { investment decision }\end{array}$ \\
\hline
\end{tabular}

Use of such a model produces biased results if time invariant unobservable individual effects are correlated to other explanatory variables (omitted variable bias). To prevent such distortions we controlled for a number of individual characteristics. These were collected via an ex-post questionnaire following the decision-making part of the experiment. The control variables included, which are intended to absorb 
distortions resulting from unobserved individual effects or explain individual behavior, are presented in Table 5. This table also provides a description of independent variables used in the regressions.

\subsection{Tax group of choice (Hypothesis 1)}

Table 6 indicates how often formula apportionment was selected as a fraction of all selections made over the course of the four treatments as well the fraction of rounds in which participants were taxed under formula apportionment. This distinction is important since, once selected, participants had to stay in the formula apportionment regime for at least five rounds.

Table 6: Portion of formula apportionment selected and effectuated

\begin{tabular}{l|cccc} 
& Owner 15 & Owner 5 & Manager 15 & Manager 5 \\
\hline Selected & 0.26 & 0.18 & 0.30 & 0,26 \\
Rounds effectuated & 0.40 & 0.31 & 0.50 & 0,41 \\
\hline \hline
\end{tabular}

To gain a better understanding of the factors driving the choice of formula apportionment, we consider the results of Regression model 1, which are presented in Table 7.

Table 7: Choice of formula apportionment as the tax regime

\begin{tabular}{lc}
\multicolumn{1}{c}{ Variables } & $1=\mathrm{FA}$ \\
\hline LCF at IO I & -0.0999 \\
LCF at IO II & $(0.0954)$ \\
& $-0.371^{* * *}$ \\
LCF at group level & $(0.0704)$ \\
& $0.239^{* * * *}$ \\
TD15 & $(0.0827)$ \\
& 0.308 \\
Manager & $(0.253)$ \\
& 0.0630 \\
Pseudo R & $(0.265)$ \\
Observation & 0.280 \\
Standard errors & 982 \\
This table contains coefficients and (in brackets) standard \\
errors for selected parameter estimates of Regression model 1. \\
The complete regression results are available in Appendix B, \\
Table B.1. Statistical significance at the 1\%, 5\% and 10\% are \\
denoted by ***, ** and *, respectively.
\end{tabular}

We observe that the treatment variables Manager and TD15 do not significantly affect the choice of formula apportionment. The significant negative coefficient of $L C F$ at IO II indicates that losses carried forward in IO II decrease the probability of 
switching the tax regime and choosing formula apportionment. Transforming the factor value of -0.371 into a marginal effect at the mean of LCF at IOII leads to a value of 9.5 percent. This implies that the probability of choosing formula apportionment would be reduced by 9.5 percent for each 10,000 units of losses carried forward. A similar influence of losses carried forward can be observed for switches from formula apportionment to separate accounting: the coefficient of LCF at group level is significantly positive. The marginal effect of LCF at group level indicates that the probability of choosing separate accounting would be reduced by 6.1 percent for each 10,000 units of losses carried forward.

To summarize, participants show a slight, though not significant, preference for separate accounting. Nonetheless, formula apportionment was considered a relevant option. Neither the tax-rate differential (TD15) nor the compensation scheme (Manager) is shown to drive the choice of tax regime. Losses carried forward (LCF at IO II and LCF at group level) prevent switching between tax regimes.

What novel insights can be derived from these results? From the perspective of the authors, the results indicate that formula apportionment provides an equivalent alternative tax regime if risk of investment ending up in a loss is taken into account. In interpreting this result, we should bring to mind the fact that empirical literature reveals transfer pricing to provide an avenue for profit shifting to lower taxing jurisdictions. What is more, looking at profitable companies empirical studies have shown that the tax-rate differential encourages profit-shifting activities available under separate accounting. In contrast, under formula apportionment companies optimize the distribution of factors entering the allocation formula across the individual tax jurisdictions. This latter planning route is, however, thought to be more expensive and may also distort investment decisions. Separate accounting is therefore considered to be more flexible with the result that the literature raises expectations for separate accounting to be more advantageous where the tax rate differential is larger. On this note, Mintz and Smart, 2004 find that taxable income of companies under separate accounting varies with tax rates to a significantly larger extent than taxable income of entities using formula apportionment. Likewise, Oestreicher and Klett, 2013, show that the tax rate differential exerts a significantly negative impact on the decision to opt for group taxation. The lacking influence of TD15 in the regression suggests that above mentioned advantages of separate accounting are diminished in the presence of uncertainty. This may be due to the possibility of offsetting losses against profits 
between investment alternatives under formula apportionment and the corresponding non-debt tax shield representing an equivalent to the potential tax planning advantages under separate accounting. These findings are supported by the observations in Büttner, Riedel, und Runkel, 2011, Oestreicher and Koch, 2010, Oestreicher and Klett, 2013 and Mintz and Weichenrieder, 2010.

The negative influence of losses carried forward on switches between taxregimes comes as no surprise because a switch would delay offsetting losses against future profits at least temporarily delay, and thus be accompanied by negative tax effects.

To conclude, in the presence of an optional formula apportionment, the choice of tax regime depends neither on the remuneration function nor on the tax-rate differential, but is driven by individual possibilities to offset losses.

\subsection{Tax-rate differential and factor allocation (Hypothesis 2)}

Table 8 provides the mean values of investments in the higher taxed IO II observed in each of the four treatments. ${ }^{12}$ Obviously, in the case of a low tax-rate differential participants allocate a larger number of production factors to IO II than in the case of a high tax-rate differential. These differences are statistically significant under both separate accounting and formula apportionment, and are independent of manager or owner compensation (for each pairwise comparison, a Wilcoxon-Mann-Whitney test $^{13}$ shows significant differences on a five-percent level).

Table 8: Investments in IO II (mean)

\begin{tabular}{l|cccc} 
& Owner 15 & Owner 5 & Manager 15 & Manager 5 \\
\hline Separate accounting & 6.72 & 9.29 & 6.83 & 8.65 \\
Formula apportionment & 4.35 & 8.14 & 7.32 & 9.75 \\
\hline \hline
\end{tabular}

Table 8 also indicates that for owners investments under formula apportionment fall below those under separate accounting, while the opposite is true for managers. However, the difference is statistically significant only in the case of formula apportionment and the high tax-rate differential (Wilcoxon-Mann-Whitney test, fivepercent significance required).

\footnotetext{
12 There is no need to consider separately the investment in IO I, since $v_{1}=15-v_{2}$.

13 Due to the requirement of independence between observations, we based the Wilcoxon-MannWhitney tests on the individual averages of the number of factors allocated to IO II.
} 
Table 9: Allocation of production factors to IO II

\begin{tabular}{|c|c|c|c|}
\hline Variables & Overall & SA & FA \\
\hline LCF at IO I & $\begin{array}{l}-0.0546 \\
(0.0434)\end{array}$ & $\begin{array}{l}-0.0983^{*} \\
(0.0513)\end{array}$ & \\
\hline LCF at IO II & $\begin{array}{l}0.0231^{*} \\
(0.0126)\end{array}$ & $\begin{array}{l}0.0249^{* *} \\
(0.0119)\end{array}$ & \\
\hline LCF at group level & $\begin{array}{l}0.00957 \\
(0.0215)\end{array}$ & & $\begin{array}{c}0.0105 \\
(0.0252)\end{array}$ \\
\hline TD15 & $\begin{array}{l}-0.343^{* * * *} \\
(0.0933)\end{array}$ & $\begin{array}{c}-0.240^{* * *} \\
(0.108)\end{array}$ & $\begin{array}{c}-0.546^{* * * *} \\
(0.147)\end{array}$ \\
\hline Manager & $\begin{array}{c}-0.126 \\
(0.0860)\end{array}$ & $\begin{array}{c}-0.106 \\
(0.0777)\end{array}$ & $\begin{array}{c}0.498^{* * *} \\
(0.174)\end{array}$ \\
\hline FA & $\begin{array}{l}-0.237^{*} \\
(0.122)\end{array}$ & & \\
\hline FA * Manager & $\begin{array}{c}0.595^{* * * *} \\
(0.169)\end{array}$ & & \\
\hline Transfer to IO I & $\begin{array}{l}0.0256^{* * * *} \\
(0.00532)\end{array}$ & $\begin{array}{l}0.0227^{* * *} \\
(0.00446)\end{array}$ & \\
\hline Transfer to Z & $\begin{array}{l}0.0245^{* * *} \\
(0.00568)\end{array}$ & $\begin{array}{l}0.0325^{* * *} \\
(0.00786)\end{array}$ & $\begin{array}{l}0.0257^{* * *} \\
(0.00877)\end{array}$ \\
\hline Detection of transfer to IO I & $\begin{array}{l}0.00273 \\
(0.0622)\end{array}$ & $\begin{array}{l}-0.0178 \\
(0.0548)\end{array}$ & \\
\hline Detection of transfer to $\mathrm{Z}$ & $\begin{array}{l}-0.0156 \\
(0.0742)\end{array}$ & $\begin{array}{c}0.0392 \\
(0.0663)\end{array}$ & $\begin{array}{l}-0.101 \\
(0.138)\end{array}$ \\
\hline $\begin{array}{l}\text { Observation } \\
\text { Standard errors }\end{array}$ & $\begin{array}{c}1.245 \\
\text { cluster robust }\end{array}$ & $\begin{array}{c}738 \\
\text { cluster robust }\end{array}$ & $\begin{array}{c}507 \\
\text { cluster robust }\end{array}$ \\
\hline
\end{tabular}

This table provides coefficients and standard errors for selected parameter estimates of Regression model 2. The complete regression results are available in Appendix B, Table B.2. Statistical significance at the $1 \%, 5 \%$ and $10 \%$ are denoted by ***** and *, respectively.

The results of Regression model 2 concerning the number of production factors allocated to IO II are presented in Table 9. They indicate a significantly negative coefficient of TD15, implying that a higher tax-rate differential leads to a significantly lower investment in the higher taxed IO II, under both separate accounting and formula apportionment. Since the coefficients of a count data model can be interpreted as semi-elasticity it emerges that an increase in tax rates by 10 percent leads to 3.43 percent and 5.46 percent less investment under separate accounting and formula apportionment, respectively. It can be seen that under formula apportionment participants remunerated as managers invest significantly more production factors in IO II than owners. Their investment is nearly 5 percent higher compared to that made by owners. In the case of owner-based compensation, the use of formula apportionment leads to significantly lower investment in IO II than under separate accounting (minus 2.37 percent). The results also make it clear that profit shifting to IO I (Profit shift to IO I) and Z (Profit shift to Z) is accompanied by larger investments in IO II (significantly positive coefficients). Under separate accounting a profit shift of 1,000 units to IO I or an identical shift to $\mathrm{Z}$ are associated with 2.56 percent or 3.25 percent 
higher investment in IO II. Under formula apportionment a profit shift to $\mathrm{Z}$ increases investment by 2.57 percent.

To summarize, the allocation of production factors is a function of the tax-rate differential, under both separate accounting and formula apportionment. Furthermore, the allocation of production factors is driven by the remuneration function. Under formula apportionment, managers invest higher amounts in the higher taxed investment object IO II than owners. Besides, the results show that a more extensive use of taxplanning alternatives leads to larger investments in high tax countries.

What is the conclusion that can be drawn from these observations? One is that investment is sensitive to the tax rate or a tax rate differential also under the separate accounting tax regime. A second conclusion is that this sensitivity depends on whether the entity is driven by owners (the SME or family business) or managers (the business of large enterprises). Although the first result is well documented by empirical studies looking at the impact of taxation on foreign direct investment (see, in particular, Feld and Heckemeyer, 2013), when focusing on profit or the profitability of companies in low taxed jurisdictions, the corresponding literature on profit shifting, however, is unable to distinguish between the shifting of 'paper profits' and the international allocation of highly profitable, in particular intangible, assets. Our study reveals that under separate accounting, profit shifting is facilitated to a large extent by attribution of assets. Although this should be clear when taking on board the fact that arm's length pricing is based on comparability factors, including in particular the allocation of functions, assets, and risks, empirical literature does not make this clear. Hence, the option between separate accounting and formula apportionment does bring with it the alternative of shifting profit or shifting assets. The difference is in the intensity to which assets are shifted to low tax countries.

In this context, we observe that the effect of the tax-rate differential is greater under formula apportionment than under separate accounting. From a policy perspective, this greater influence is important because a change in the allocation of production factors means changing the allocation formula (in our experiment the numbers of employees as required by the technology underlying the production function). Regarding an optional formula apportionment regime this would suggest that the economic values underlying the allocation formula will be allocated to low tax countries.

With respect to the difference between decisions made from the manager or owner perspective, the more intensive investment in the higher taxed IO II by managers as 
compared with owners might be traced back to the different tax rates applicable in the separate accounting and formula apportionment contexts. Profits in IO II are taxed at a lower combined tax rate under formula apportionment than under separate accounting. In the case that IO II incurs losses the amount of these losses increases with the number of production factors invested. In contrast to owners, managers do not have to bear any loss. This leads to larger investments by managers than by owners in the more productive investment object IO II. Owners tend to allocate production factors in a more risk-avoiding manner, splitting available production factors more equally between IO I and IO II because making losses would directly reduce their compensation.

The positive relationship observed between profit shifting and investments in IO II suggests that corporations deal with the tradeoff between productivity and taxation by making use of tax-planning activities. This can have interesting political implications: by "closing one's eyes" to profit shifting, additional investment can be attracted.

\subsection{Transfer to IO I (Hypothesis 3)}

This kind of intra-group transfer applies only to separate accounting. As to the factors influencing the amounts of profit shifted intra-group, a first issue concerns the tax rate differential. We expect that the amount of profits shifted between group companies is positively correlated with the tax rate differential (Hypothesis 3a). A second issue concerns the existing remuneration scheme. Where decisions are made from the owner perspective, the amounts of profits shifted to low-tax jurisdictions are expected to be higher than is the case where the decisions are made by managers who receive a fixed income plus a performance bonus but do not participate in a loss (Hypothesis $3 b)$.

Table 10 provides the average amounts of profit shifted to IO I over the course of the four treatments. The Kruskal-Wallis test shows that these differences are statistically not significant.

Table 10: Amounts of profits shifted to IO I

\begin{tabular}{l|cccc} 
& Owner 15 & Owner 5 & Manager 15 & Manager 5 \\
\hline Separate accounting & 2,441 & 5,904 & 5,779 & 5,781 \\
Formula apportionment & n/a & n/a & n/a & n/a \\
\hline \hline
\end{tabular}


Table 11 presents the results of Regression model 3.

Table 11: Profit shifts to IO 1

\begin{tabular}{lc}
\multicolumn{1}{c}{ Variables } & LN profit shift to IO 1 \\
\hline LCF at IO I & -0.127 \\
LCF at IO II & $(0.0863)$ \\
& $-0.256^{* * *}$ \\
TD15 & $(0.0750)$ \\
& $-1.265^{*}$ \\
Manager & $(0.742)$ \\
& $1.183^{*}$ \\
Investment in IO II & $(0.669)$ \\
& $0.127^{* *}$ \\
Transfer to Z & $(0.0498)$ \\
& 0.0993 \\
Detection of transfer to IO I & $(0.158)$ \\
& $0.713^{*}$ \\
Detection of transfer to Z & $(0.392)$ \\
& $-1.134^{* *}$ \\
$\mathrm{R}^{2}$ & $(0.512)$ \\
Observation & 0.265 \\
Standard errors & 738 \\
\hline This table contains coefficients and standard errors for selected \\
parameter estimates of Regression model 3. The complete regres- \\
sion results are available in Appendix B, Table B.3. Statistical \\
significance at the 1\%, 5\% and 10\% are denoted by ***** and * \\
respectively.
\end{tabular}

We observe that participants do shift profits to the lower taxed IO I. This profit shifting is higher/lower where the tax rate differentials are low/high (significant negative coefficient of TD15). We also observe that managers make greater use of accounting leeway than owners (significant positive coefficient of Manager). The significant positive coefficient of Investment in IO II indicates that larger investments in IO II is associated with higher profit shifting activities. Since the coefficients can be interpreted in terms of semi-elasticities, it can be inferred that one additional production factor invested in IO II brings with it increase in profit shifting by 1.27 percent. Large loss carry-forwards reduce the amount transferred (highly significant coefficient of LCF at IO II). Specifically, an increase in losses carried forward at IO II by 10,000 units decreases profit shifting by 2.56 percent. Intra-group transfers are also influenced by conducted tax audits in prior periods. A detection of transfers to IO I boosts profit shifting in future periods by 7 percent (significant positive coefficient of Detection of transfer to $I O I$ ) whereas the fact that income transfer to $\mathrm{Z}$ is detected brings with it to a reduction of profit shifting activities by 11.3 percent (significant negative coefficient of Detection of transfer to IO Z).

To summarize, the results make it clear that profit shifting to IO I is a function of the tax-rate differential. Profit shifting to IO I is negatively correlated with the tax-rate 
differential. What is more, compared to owners, managers tend to transfer higher amounts intra-group. The detection of profit shifting from IO II to IO I is linked with higher tax-planning activities in the following periods, whereas the detection of profit shifts to $\mathrm{Z}$ in the prior period leads to the opposite result. Finally, higher investments in high tax countries give rise to larger transfer pricing activities.

With a view to interpretation: Lower amounts of profits shifted in situations where the tax-rate differentials are high may reflect the fact that in this case risk of penalty payments is limited and negative consequences in the case of losses are reduced. Together with the observation that, relative to the simulation outcomes, owners allocate on average the "right" number of factors to IO II but transfer lower amounts, the observation that owners shift a lower amount of profit than managers suggests that loss aversion could play a role (Tversky and Kahnemam, 1979; Kahneman, Knetch and Thaler, 1990). In addition to a payment reduction in the case of a tax audit, a probably more painful loss is experienced in the case that profit has been shifted from IO II to IO I but then a loss occurs (with a probability of 30 percent) in IO II. Since managers are not accountable for losses, they might be more willing than owners to take the risk of such losses. Note that we do not observe such an effect with regard to transfers to an additional investment object. Due to the higher detection rate, the amounts shifted are generally lower there than the transfers to IO I and, specifically, in the case of formula apportionment the risk of a loss of the group is lower than the risk of a loss in IO II under separate accounting.

What is more, the possibility of shifting profits from IO II to IO I depends on the number of production factors previously allocated to IO II (see section 5.3). Besides the simple relationship that the more profits accrue to the high taxed jurisdiction, the more profits can be allocated to the lower taxed jurisdiction, this result also indicates that under separate accounting participants make use of both avenues for profit shifting, i.e., allocating assets to the low taxed investment alternative and shifting 'paper' profits. In the latter planning alternative, the participants anticipate the higher productivity and pre-tax earnings of IO II (instead of making the investment decision on the basis of post-tax earnings as was shown in section 5.3) and shift this additional pre-tax profit to the lower taxed investment object IO I. This means that the tradeoff effect between productivity and tax is reduced by intra-group profit shifting. The negative correlation between intra-group profit shifting and losses carried forward show that the reduction of loss carry forwards is preferred to profit shifting activities. This 
behavior is understandable because offsetting a gain against losses carried forward generates an immediate reduction of tax payments without the risk of being detected by the tax authorities, if profit shifting is carried out.

The positive influence of the detection of profit shifting to IO I in the prior period is in line with the effect identified by Mittone (2006) in experiments on tax evasion behavior that where tax evasion is detected in a previous period, tax evasion is carried out to an even greater extent in the following period ("bomb crater effect") . This effect is similar to the so called gamblers fallacy often reported with respect to decisions made under uncertainty (e.g., in the insurance literature). The negative influence of detection of profit shifting to the additional investment object $Z$ could relate to the so-called availability hypothesis: the observation of a detection in one area could increase the perceived probability of being audited in the other next time.

\subsection{Transfer to additional investment object (Hypothesis 4)}

Table 12 indicates the average amounts of profits shifted to the additional investment object $\mathrm{Z}$ in the four treatments. We find that the amounts of profits shifted vary as a function of the tax regime, the tax rate differential, and partially the remuneration scheme. However, based on a Kruskal-Wallis test, the comparison of these amounts of profit shifted to the additional investment object $\mathrm{Z}$ shows no significant differences, either for separate accounting or for formula apportionment.

Table 12: Amounts of profits shifted to Z

\begin{tabular}{l|cccc} 
& Owner 15 & Owner 5 & Manager 15 & Manager 5 \\
\hline Separate accounting & 1,828 & 843 & 1,296 & 969 \\
Formula apportionment & 2,689 & 2,747 & 1,616 & 1,784 \\
\hline \hline
\end{tabular}

It can be seen in Table 13 that the compensation scheme does not influence profit shifting to Z. Under separate accounting TD15 reduces profit shifting to Z by 1.26 percent (statistical significance at the ten percent level), whereas under formula apportionment no effect can be observed. What is more, the analysis shows that loss carryforwards reduce transfers to $\mathrm{Z}$ (statistical significant negative coefficients of $L C F$ at IO I, LCF at IO II and LCF at group level). Use of formula apportionment rather than separate accounting increases profit shifting to $\mathrm{Z}$ by 18.11 percent (significant positive coefficient of $F A$ ). 
Table 13: Profit shifts to the additional investment object $\mathrm{Z}$

\begin{tabular}{lccc}
\multicolumn{1}{c}{ Variables } & Overall & LN transfer to Z & FA \\
\hline LCF at IO I & $-0.110^{* * *}$ & -0.0875 & \\
LCF at IO II & $(0.0516)$ & $(0.0556)$ & \\
& $-0.146^{* *}$ & $-0.135^{*}$ & $-0.289^{* *}$ \\
LCF at group level & $(0.0739)$ & $(0.0702)$ & $(0.143)$ \\
& $-0.262^{* *}$ & & -0.118 \\
TD15 & $(0.123)$ & $-1.259^{*}$ & $(0.801)$ \\
& -0.642 & $(0.655)$ & 0.241 \\
Manager & $(0.610)$ & 0.328 & $(0.813)$ \\
& 0.299 & $(0.636)$ & \\
FA & $(0.573)$ & & \\
& $1.811^{* * *}$ & 0.0600 & \\
Transfer to IO I & $(0.420)$ & $(0.0451)$ & 0.0187 \\
& 0.0405 & -0.0304 & $(0.0389)$ \\
Investment in IO II & $(0.0396)$ & $(0.0420)$ & \\
& -0.00663 & -0.151 & 0.354 \\
Detection of transfer to IO I & $(0.0313)$ & $(0.306)$ & $(0.398)$ \\
& 0.0214 & 0.112 & 0.213 \\
Detection of transfer to Z & $(0.313)$ & $(0.490)$ & 507 \\
& 0.421 & 0.179 & cluster robust \\
R & $(0.298)$ & cluster robust & \\
Observation & 0.195 & 1.245 & \\
Standard errors & cluster robust & & \\
\hline
\end{tabular}

This table provides coefficients and standard errors for selected parameter estimates the main explanatory variables of Regression model 3. The complete regression results are available in Appendix B, Table B.4. Statistical significance at the $1 \%, 5 \%$ and $10 \%$ are denoted by ${ }^{* * * * * *}$ and ${ }^{*}$, respectively.

To summarize, the difference in tax rates has only a weak (negative) influence on the transfer to $\mathrm{Z}$ if separate accounting is used while according to our simulated solution presented above, regardless of the remuneration function this relationship should be positive. Furthermore the results indicate that even where the tax rate differential is low, participants shift relevant amounts to Z. High impact can be observed with respect to the tax regime ('FA'). Under formula apportionment the amount of profits shifted increases substantially. In cases where there are loss carry-forwards, profit shifting to $\mathrm{Z}$ is reduced.

Given the non-existent or at least minor influence of the remuneration function and the tax-rate differential, we interpret these results as showing that participants make the transfer decision dependent on variable factors such as the current tax-regime or loss carry forwards, rather than on fixed factors relating to the treatment parameters. Lower profit shifting activities (under separate accounting) in the case of a high taxrate differential might again reveal an intention to avoid tax audits and subsequent additional payments as these are higher than in the case of a low tax-rate differential (see section 5.4). An additional point of relevance may be the fact that the probability and, hence, the risk that 'paper' profit shifting is detected in a subsequent tax audit is 
higher in the case of transfers to $\mathrm{Z}$ as compared to transfers intra-group. Moreover, the results indicate that participants shift profits more intensively to the additional investment object $\mathrm{Z}$ if formula apportionment is used. This extensive use of accounting leeway is particularly interesting since, according to our simulation results, profit shifting to $\mathrm{Z}$ should be lower if formula apportionment is used. This finding implies that under the facts and circumstances of the case at hand the tax saving effect of transferring profits to investment alternatives outside the consolidated group is overestimated. The observation, however, that decision makers exploit such profit shifting opportunities that arise from statutory tax-rate differentials within the group (i.e., shifting profit to companies that are excluded from consolidation) is in line with the literature (Büttner, Riedel, and Runkel, 2011). We can conclude that, in the case of optional formula apportionment and the existence of affiliated companies outside the tax group, profit shifting to affiliated companies will continue to take place as a tax planning measure among multinational enterprises.

Participants reduce the use of accounting leeway if a loss carry forward exists. This effect is independent of the tax regime selected. Obviously, when possible, participants prefer to reduce the tax burden of the actual period by profit-loss offsets rather than risky profit-shifting activities.

\section{Conclusion}

The aim of the present paper is to research experimentally the choice of tax regime (separate accounting or formula apportionment) in the presence of uncertain returns on investment, varied tax rate differentials, and differing compensation schemes. In this context, we look into the impact of this tax regime choice on profit shifting and possible losses to be carried forward. In addition, the effect of the tax regime on taxplanning activities, in particular the allocation of production factors is investigated. Our results should provide indications as to companies' behavior if an optional formula apportionment regime were to be introduced in Europe.

In line with our numerical simulations, the results of our experiment indicate no significant differences in the choice of the tax regime as a function of both the tax rate differential and the remuneration (Hypothesis 1). However, our results show that, despite the fact that separate accounting is considered to be more flexible in terms of profit shifting, an optional regime of group taxation is a relevant option that will be exploited by multinationals. Lacking influence of the tax rate differential suggests 
that said advantages of separate accounting are diminished in the presence of uncertainty. The main reason for the resulting equivalence of separate accounting and formula apportionment could be the fact that formula apportionment offers intra-group loss-offset, cushioning expected cash flow disadvantages in the case that investment runs the risk of culminating in a loss.

We demonstrate that in both tax regimes the allocation of production factors is dependent upon the tax rate differential, and that higher tax rates lead to lower amounts of investment (Hypothesis 2). However, the tax rate differential between countries becomes much more important if formula apportionment is used. What is more, the choice of tax regime influences the allocation of production factors in such a way that owners tend to invest less in high taxing countries, while managers do the reverse if formula apportionment is used. These results show that investments are sensitive to the tax rate or the tax rate differential, also under the separate taxation regime. Moreover, it becomes clear that this sensitivity depends on whether the investment is carried out by owners or managers of the business.

Regarding profit shifts, under separate accounting our results indicate that the amount of profits shifted is a function of the tax-rate differential (Hypothesis $3 a$ ) and the remuneration function (Hypothesis $3 b$ )). This result provides evidence that under separate accounting, participants make use of both avenues for profit shifting, i.e., allocation of profitable assets to the low taxed investment alternative and shifting 'paper' profits. Lower amounts of profits shifted in situations where the tax rate differentials are high may reflect the fact that in this case risk of penalty payment is limited and negative consequences in the case of losses are reduced. What is more, we are able to demonstrate that managers tend to use accounting leeway to a greater extent compared to owners.. A reason for this could be the fact that the negative influence of additional subsequent payments on the compensation function is limited.

Profit shifting to the additional object $Z$ only reacts to the size of the tax-rate differential (Hypothesis 4) if separate accounting is used. Again, the tax-rate differential negatively influences the amount of profits shifted. However, another observation might be of yet greater significance. We find that profit shifts to $\mathrm{Z}$ are significantly higher under formula apportionment than under separate accounting. With a view to the planned СССТВ this observation suggests that multinational enterprises opting for taxation on a consolidated basis are likely to use alternative investment locations and shift profits outside the European Union. 


\section{References}

Aaron, H.J., Boskin, M.J. (Eds.), 1980. The Economics of taxation: The States Corporate Income Tax: Lab in Wolves' Clothing. Brookings Institution, Washington, D.C.

Alvarez, L. H. R., Kanniainen, V., Södersten, J., 1998. Tax policy uncertainty and corporate investment: A theory of tax-induced investment spurts. J. Public Econ. 69 (1), 17-48. 10.1016/Soo47-2727(97)0oo88-1.

Alvarez, L. H. R., Koskela, E., 2008. Progressive Taxation, Tax Exemption, and Irreversible Investment under Uncertainty. Journal of Public Econ.Theory 10 (1), 149-169. 10.1111/j.1467-9779.2008.00356.x.

Andreas, J., Rapp, M., Wolff, M., 2012. Determinants of director compensation in two-tier systems: evidence from German panel data. Rev. Manag. Sci. 6 (1), 33-79. 10.1007/s11846-010-0048-z.

Arachi, G., Biagi, F., 2005. Taxation, cost of capital and investment: Do tax asymmetries matter? G. degli econ. annali econ. 64 (2/3), 295-321.

Bartelsman, E.J., Beetsma, Roel M. W. J., 2003. Why pay more? Corporate tax avoidance through transfer pricing in OECD countries. J. Public Econ. 87 (9-10), 2225-2252. 10.1016/Soo47-2727(02)0oo18-X.

Bernard, J.-T., Weiner, R., 1990. Multinational corporations, transfer prices and taxes: Evidence from the US petroleum industry, in: Slemrod, J., Razin, A. (Eds.), Taxation in the global Economy, Chicago, pp. 123-154.

Buettner, T., Overesch, M., Schreiber, U., Wamser, G., 2011. Corporation taxes and the debt policy of multinational firms. Z Betriebswirtsch 81 (12), 1325-1339. 10.1007/s11573-011-0520-5.

Buettner, T., Riedel, N., Runkel, M., 2011. Strategic Consolidation under Formula Apportionment. Nat. Tax J. 64 (2), 225-254.

Cameron, A.C., Trivedi, P.K., 2010. Microeconometrics using Stata. Stata Press, College Station, Tex.

Clausing, K.A., 2003. Tax-motivated transfer pricing and US intrafirm trade prices. J. Public Econ. 87 (9-10), 2207-2223. 10.1016/Soo47-2727(02)ooo15-4. 
Collins, J., Kemsley, D., Lang, M., 1998. Cross-Jurisdictional Income Shifting and Earnings Valuation. J. 36 (2), 209-229. 10.2307/2491475.

Creedy, J., Gemmell, N., 2011. Corporation tax asymmetries: effective tax rates and profit shifting. Int. Tax Public Finance 18 (4), 422-435. 10.1007/s10797-011-9165O.

Devereux, M.P., 1989. Tax Asymmetries, the Cost of Capital and Investment: Some Evidence from United Kingdom Panel Data. Econ. J. 99 (395), 103-112. $10.2307 / 2234073$.

Devereux, M.P., Keen, M., Schiantarelli, F., 1994. Corporation tax asymmetries and investment: Evidence from U.K. panel data. J. Public Econ. 53 (3), 395-418. 10.1016/0047-2727(94)90032-9.

Dharmapala, D., Riedel, N., 2013. Earnings shocks and tax-motivated incomeshifting: Evidence from European multinationals. J. Public Econ. 97 (o), 95-107. 10.1016/j.jpubeco.2012.08.004.

Dreßler, D., Overesch, M., 2013. Investment impact of tax loss treatment-empirical insights from a panel of multinationals. Int. Tax Public Finance 20 (3), 513-543. 10.1007/s10797-012-9240-1.

Edmiston, K.D., 2002. Strategic Apportionment of the State Corporate Income Tax. Nat. Tax J. 55 (2), 239-262.

Edmiston, K.D., 2004. Tax Uncertainty and Investment: A Cross-Country Empirical Examination. Econ. Inquiry 42 (3), 425-440. 10.1093/ei/cbho71.

Edmiston, K.D., Arze del Grando, J., 2006. Economic Effects of Apportionment Formula Changes: Results from a Panel of Corporate Income Tax Returns. Public Finance Rev. 34 (5), 483-504. 10.1177/1091142106289016.

Egger, P., Eggert, W., Winner, H., 2010. Saving taxes through foreign plant ownership. J. Int. Econ. 81 (1), 99-108. 10.1016/j.jinteco.2009.12.004.

European Commission, 2011. Proposal for a Council Directive on a Common Consolidated Corporate Tax Base (CCCTB). COM(2011) 121/2, 2011,00058 (CNS), Brussels.

Feld, L.P., Heckemeyer, J.H., 2011. FDI and Taxation: A meta-study. J. Econ. Surveys $25(2), 233-272$. 
Feld, L.P., Heckemeyer, J.H., Overesch, M., 2013. Capital structure choice and company taxation: A meta-study. J. Banking \& Finance 37 (8), 2850-2866. 10.1016/j.jbankfin.2013.03.017.

Fischbacher, U., 2007. z-Tree: Zurich toolbox for ready-made economic experiments. Exp. Econ. 10 (2), 171-178. 10.1007/s10683-006-9159-4.

Gérard, M., 2006. Reforming the taxation of multijurisdictional enterprises in Europe: coopetition in a bottom-up federation 1860, München. http://hdl.handle.net/10419/25905.

Gérard, M., 2007. Reforming the Taxation of Multijurisdictional Enterprises in Europe. CESifo Econ. 53 (2), 329-361. 10.1093/cesifo/ifmo12.

Giovannini, A., Hubbard, R.G., Slemrod, J. (Eds.), 1993. Income shifting in US multinational corporations.

Goolsbee, A., Maydew, E.L., 2000. Coveting thy neighbor's manufacturing: the dilemma of state income apportionment. J. Public Econ. 75 (1), 125-143. 10.1016/Soo47-2727(99)ooo36-5.

Gordon, R., Wilson, J.D., 1986. An Examination of Multijurisdictional Corporate Income Taxation under Formula Apportionment. Econometrica 54 (6), 1357-1373. $10.2307 / 1914303$.

Gries, T., Prior, U., Sureth, C., 2012. A Tax Paradox for Investment Decisions under Uncertainty. J. Public Econ. Theory 14 (3), 521-545. 10.1111/j.14679779.2012.01547.x.

Grubert, H., Mutti, J., 1991. Taxes, Tariffs and Transfer Ricing in Multinational Corporate Decision Making. Rev. Econ. \& Statistics 73 (2), 285.

Grubert, H., Mutti, J., 2000. Do Taxes Influence Where U.S. Corporations Invest? Nat. Tax J. 53 (4), 825-839.

Gupta, S., Hofmann, M.A., 2003. The Effect of State Income Tax Apportionment and Tax Incentives on New Capital Expenditures. J. American Tax. Association 25, 125.

Hanlon, M., Heitzman, S., 2010. A review of tax research. J. Account. and Econ. 50 (2-3), 127-178. 10.1016/j.jacceco.2010.09.002. 
Harris, D.G., 1993. The Impact of U.S. Tax Law Revision on Multinational Corporations' Capital Location and Income-Shifting Decisions. J. 31, 111-140. $10.2307 / 2491167$.

Harris, D.G., Morck, R., Slemrod, J., Yeung, B., 1993. Income shifting in U.S. multinational corporations, in: Giovannini, A., Hubbard, R.G., Slemrod, J. (Eds.), Income shifting in US multinational corporations, pp. 277-307.

Heckemeyer, J.H., Overesch, M., 2013. Multinationals' profit response to tax differentials: Effect size and shifting channels. ZEW, Mannheim.

Huizinga, H., Laeven, L., 2008. International profit shifting within multinationals: A multi-country perspective. J. Public Econ. 92 (5-6), 1164-1182. 10.1016/j.jpubeco.2007.11.002.

Kahneman, D., Knetsch, J., Thaler, R., 1990. Experimental test of the endowment effect and the Coase Theorem. J. Pol. Econ. 98 (6), 1325-1348.

Kahneman, D., Tversky, A., 1979. Prospect theory: An analysis of decision under risk, Econometrica, Vol. 47 (2), 263-291.

Klassen, K.J., Lang, M., Wolfson, M., 1993. Geographic Income Shifting by Multinational Corporations in Response to Tax Rate Changes. J. Account. Research 31, 141-173. 10.2307/2491168.

Klassen, K.J., Laplante, S.K., 2012. Are U.S. Multinational Corporations Becoming More Aggressive Income Shifters? J. Account. Research 50 (5), 1245-1285. 10.1111/j.1475-679X.2012.00463.x.

Klassen, K.J., Shackelford, D.A., 1998. State and provincial corporate tax planning: income shifting and sales apportionment factor management. J. Account. Econ. 25 (3), 385-406. 10.1016/So165-4101(98)00028-7.

Mackie-Mason, J.K., 1990. Some nonlinear tax effects on asset values and investment decisions under uncertainty. J. Public Econ. 42 (3), 301-327. 10.1016/00472727(90)90019-E.

Mintz, J.M., 1999. CESifo Conference "Capital Income Taxation - Policy Requirements for Europe" - Globalization of the Corporate Income Tax The Role of Allocation. FA: Public Finance Anal. 56 (3-4), 389-423. 
Mintz, J.M., Smart, M., 2004. Income shifting, investment, and tax competition: theory and evidence from provincial taxation in Canada. J. Public Econ. 88 (6), 11491168. 10.1016/Soo47-2727(03)0oo6o-4.

Mintz, J.M., Weichenrieder, A.J., 2010. The indirect side of direct investment: Multinational company finance and taxation. MIT Press, Cambridge, Mass.

Mittone, L., 2006. Dynamic behaviour in tax evasion: An experimental approach. J. Socio-Econ. 35 (5), 813-835. 10.1016/j.socec.2005.11.065.

Niemann, R., Sureth, C., 2004. Tax neutrality under irreversibility and risk aversion. Econ. Letters 84 (1), 43-47. 10.1016/j.econlet.2003.12.010.

OECD, 2013. Action Plan on Base Erosion and Profit Shifting. OECD Publishing.

OECD, 2013. Addressing Base Erosion and Profit Shifting. OECD Publishing.

Oestreicher, A., Koch, R., 2010. The determinants of opting for the German group taxation regime with regard to taxes on corporate profits. Rev. Manag. Sci. 4 (2), 119-147. 10.1007/s11846-009-0036-3.

Oestreicher, A., Koch, R., 2012. Taxation and corporate group structure - Evidence from a sample of European multinationals. Schmalenbach Rev. 64 (4), 254-280.

Oestreicher, A., Klett, M., 2013, Optional Formula Apportionment and Tax Planning, Working paper, Göttingen

Ramb, F., Weichenrieder, A.J. Taxes and the financial structure of German inward FDI. Economic Research Centre, Frankfurt, M.

Riedel, N., 2010. The downside of formula apportionment: evidence on factor demand distortions. Int. Tax Public Finance 17 (3), 236-258. 10.1007/s10797-009-9116-1.

Schmölders, G., 1960. Das Irrationale in der öffentlichen Finanzwirtschaft: Probleme der Finanzpsychologie. Rowohlt, Hamburg.

Schmölders, G., 1970. Finanz- und Steuerpsychologie: Das Irrationale in der öffentlichen Finanzwirtschaft. Rowohlt, Reinbek bei Hamburg.

Simon, H.A., 1957. Models of man, social and rational: Mathematical essays on rational human behavior in a social setting. Wiley, New York.

Slemrod, J., Razin, A. (Eds.), 1990. Taxation in the global Economy, Chicago. 
Sureth, C., 2002. Partially Irreversible Investment Decisions and Taxation under Uncertainty: A Real Option Approach. Ger. Econ. Rev. 3 (2), 185.

Swenson, D.L., 2001. Tax Reforms and Evidence of Transfer Pricing. Nat. Tax J. 54 (1), 7-25.

Weiner, Joann Eileen Martens, 1994. Company Taxation for the European Community: Show Sub-national Tax Variation Affects Business in the United States and Canada. Ph.D. dissertation.

Wooldridge, J.M., 2010. Econometric analysis of cross section and panel data, 2nd ed. MIT Press, Cambridge, Mass. 
The CCCTB option - an experimental study

Claudia Keser, Gerrit Kimpel and Andreas Oestreicher

Appendix A: Instructions manual

(Manager 15) 


\section{Instructions for participation in the experiment}

Over the course of 15 periods, you will make individual decisions as the responsible representative of a group of companies. At the beginning of the experiment you will have the chance to practice your decision-making in three trial runs. The decisions concerned involve periodical investment decision and selection among alternatives for action in the context of taxation.

\section{The investment alternatives}

You can allocate production factors to two investment objects, IO I and IO II. Each investment object must be allocated at least one production factor. A total of $\mathbf{1 5}$ production factors are available and you are requested, please, to allocate them all to IO I and IO II.

IO I and IO II yield returns which are uncertain and differ in amount. Each investment object yields positive returns ("profit") with 70 percent probability (ie in seven out of ten cases). In 30 percent of cases (i.e. three out of ten), each investment object yields a negative return ("loss"). These probabilities apply for both IO I and IO II.

Table 1, column (1) to (6), shows the profits or losses of IO I and IO II depending on the allocation of the production factors to the two investment objects. We take account of the fact that if you attribute " $n$ " production factors to IO I, exactly " 15 - n" production factors are left for IO II. Columns (7) to (10) show the total profit or loss resulting in each case from the allocation of the production factors in the four possible profit and loss situations (ranging from profit in both investment objects to loss in both investment objects).

\section{Taxation of the investment objects}

Profits are taxed. The tax rate applicable to IO I is 15 percent and that for IO II is 30 percent. Losses are not taxed.

\section{Alternatives for action in the taxation context}

You have several alternatives for action in order to influence your tax burden. 


\section{Separate taxation of the investment objects \\ 1.1. Basics}

The profits made depending on the number of production factors allocated are taxed at the given rates of 15 to 30 percent respectively. A loss incurred in an investment object is not taxed and can be carried forward to future periods. This loss carryforward can be set off against future positive income from this investment object, thereby reducing the future tax burden.

You can influence the tax burden of IO I and IO II by changing the allocation of production factors.

Table 2 shows the overall profits and losses for IO I and IO II and the total return (before and after tax) depending on the allocation of the production factors to the two investment objects in the four possible profit and loss situations (columns (7) to (10)).

You can decrease the pre-tax returns made by one of the two investment objects by lowering the amount you report. To do this, you have two possible courses of action available which you can also use in combination.

\subsection{Making use of accounting leeway}

To do this, you have two possible courses of action available which you can also use in combination.

\subsubsection{Shifting of profit from IO II to IO I}

You have the option of determining an amount which lowers the pre-tax return of IO II (tax rate 30 percent). This amount increases IO I's pre-tax returns correspondingly (tax rate 15 percent). You have a free hand in choosing the sum you shift up to the amount of any (positive) pre-tax profit generated by IO II (depending on your allocation of production factors).

The tax consequences of a reported shift depend on the profit and loss situations that emerge. They are explained below.

- Profit I / Profit II: Looking at the pre-tax returns, the amount that you have shifted from IO II to IO I is taxed at a rate of 15 percent (instead of 30 
percent). This means that there is a tax reduction amounting to 15 percent of the reporting difference.

- Profit I / Loss II: The amount you shift from IO II to IO I increases the pretax profit of IO I and is taxed at a rate of 15 percent. At the same time the loss incurred by IO II decreases. This means the tax burden of this period increases by 15 percent of the amount you shift. The loss carry-forward associated with IO II is raised in the amount of the reporting difference. In the following periods the loss carry-forward can be set off against IO II's future profits which would normally be subject to a tax rate tax rate of 30 percent.

- Loss I / Profit II: The amount you shift from IO II to IO I can be set-off immediately against the loss incurred by IO I. This means there is an immediate tax reduction of up to 30 percent of the reporting difference (provided that the shifted amount is lower than the loss incurred by IO I. Otherwise the amount exceeding this loss is taxed at a rate of 15 percent). Due to the profit shift, IO I's loss carry-forward is reduced by the reporting difference and in subsequent periods can no longer be offset against IO I's future profits (tax rate 15 percent).

- Loss I / Loss II: In this case no immediate tax consequences arise. Your overall pre-tax result is identical to the after-tax overall result. The only consequences that arise concern the amount of loss carry-forwards. Due to the profit shift, IO II's loss carry-forward is raised by the reporting difference. It can be offset against future profits of IO II (tax rate 30 percent). At the same time IO I's loss carry-forward is reduced by the reporting difference and in subsequent periods can no longer be offset against future profits of IO I (tax rate 15 percent).

This use of accounting leeway is subject to audit by the tax authorities and is therefore not necessarily free of charge. An additional tax payment can be assessed, the amount of which depends on the shifted amount. This payment is calculated from the tax rate of 0.15 (30 percent minus 15 percent), the shifted amount and a 1.25 "penalty factor". The probability of an additional subsequent payment equals the shifted amount times 0.00002. This means the probability of an additional payment arising increases by 0.2 percent with every additional 100 units you shift. For purposes of 
orientation Table 3a shows the probability of an additional subsequent payment and its amount, for selected amounts you might choose to shift.

\subsubsection{Shifting of profit from IO II to an additional investment object}

You have the option of shifting amounts from IO II to an additional investment object. This reduces the IO II returns. If IO II shows profits, the tax burden is reduced by 30 percent of the shifted amount. At the same time, the shifted amount is added to the additional investment object and is taxed at a rate of 15 percent (instead of 30 percent at the level of IO II). You have a free hand in choosing the sum you shift up the amount of any (positive) pre-tax profit of IO II (depending on your allocation of production factors). Please also bear in mind that the sum of the shifted amount (shifting from IO II to IO I and shifting from IO II to the additional investment object may not exceed any pre-tax profit of IO II (depending on your allocation of production factors).

This use of accounting leeway is subject to audit by the tax authorities and is therefore not necessarily free of charge. An additional tax payment can be assessed, the amount of which depends on the shifted amount. This payment is calculated from the tax rate differential of 0.15 (30 percent minus 15 percent), the shifted amount and a 1.25 "penalty factor" (the additional payment equals 15 percent multiplied by the shifted amount multiplied by 1.25). The probability of an additional subsequent payment equals the shifted amount times 0.0001. This means the probability of an additional payment arising increases by 1 percent with every additional 100 units you shift. For purposes of orientation, Table $3 \mathrm{~b}$ shows the probability of an additional subsequent payment, and its amount, for selected amounts you might choose to shift.

\section{Group taxation}

\subsection{Basics}

Under group taxation, the pre-tax returns made by IO I und IO II are totaled. By totaling profits, any losses incurred by one investment object can be offset against losses of the other. The totaled return is taxed at a combined tax rate (Table 4, column (5)) which depends on the share of payroll costs associated with the investment objects. These payroll shares depend directly on the pre-tax returns of IO I and IO II. The payroll shares are presented in Table 4, column (3) and (4). Moreover, Table 4, columns (7), (9), (11) and (13) presents the after-tax return in the four possible profit 
and loss situations (ranging from profit in both investment objects to loss in both investment objects)

Should a loss be incurred, this can be carried forward to future periods (loss carryforward). This loss carry-forward can be set-off against future positive returns, thereby reducing the future tax burden.

Implementation of the group taxation regime is not free of charge. It gives rise to oneoff fixed expenses in the amount of 3.300. If you opt for this alternative tax regime you are required to stay within it for five periods. In the case that loss carry-forwards exist at the level of IO I and/or IO II the group taxation regime leads to the consequence that for this period pre-consolidated losses to be carried forward are "frozen" for the period of application. This means that they can be used only when the group taxation regime has finished, at which point they can be set-off again against profits of IO I and/or IO II. Should a loss carry-forward exist for the group when use of group taxation is ended, this is irrevocably lost.

\subsection{Change in deployment ratio of production factor}

In order to make an impact on tax burden you can change the ratio of production factor. The allocation influences the returns and combined tax rate depending on the shares of payroll.

\subsection{Shifting of profit to an additional investment object}

You have the option of reducing the overall pre-tax returns of IO I and IO II by shifting an amount to the benefit of an additional investment object. You have a free hand in choosing the amount shifted up to the amount of any (positive) of IO an IO II pretax profit (depending on your allocation of production factors). This shift has the consequence that the total profit subject to group taxation is reduces by this reporting difference. The shifted return is subject to a tax rate of 15 percent at the level of the additional investment object (instead of the combined payroll allocation dependent tax rate relevant in the group context.

This utilization of accounting leeway is subject to audit by the tax authorities and is, hence, not necessarily free of charge. An additional tax payment can be charged, the amount of which depends on the reporting difference. This payment is calculated from the tax rate differential (combined tax rate minus 15 percent), the shifted 
amount and a 1.25 "penalty factor" (the additional payment equals 15 percent multiplied by the shifted amount multiplied by 1.25). The probability of an additional subsequent payment equals the shifted amount times 0.0001. This means the probability of an additional payment arising increases by 1 percent with every additional 100 units you shift. For purposes of orientation, Table 5a shows the probability of an additional subsequent payment for selected amounts you might choose to shift. The size of the additional subsequent payment depends on your allocation of production factors, and can be viewed by clicking the button "show consequences".

\section{The decision making process}

1. You decide whether you wish to opt for separate taxation of the investment objects or group taxation. If you opt for group taxation (see section 2.1) this step is not applicable during the subsequent four periods following the first period of group taxation. After these five periods the separate accounting option becomes available again.

2. Depending on your choice of tax regime you make the investment decision (allocation of production factors) and decide whether or not you wish to make use of accounting leeway

\section{If you have opted for separate taxation of the investment ob-} jects, please note that your investment decision has an impact on your after-tax result.

Moreover you have to decide,

- what profit amount you wish to shift from IO II to IO I. Should you decide not to make a transfer, enter the value "o”.

- what profit amount you wish to shift from IO II to an additional object. Should you decide not to make a transfer, enter the value "o".

If you have opted for group taxation, please note that your investment decision has consequences for the taxation of the relevant share in payroll cost under group taxation 
Moreover you have to decide,

- what profit amount you wish to shift from IO I and IO II to an additional object. Should you decide against making any transfer please enter a value of "o".

Please note that having entered your investment decision you can obtain a summary of your entries by clicking the button "show consequences". For the four possible profit-and-loss-situations arising from your factor allocation you will see the resulting pre-tax results, the profit amount(s) you shifted and the corresponding probability of an additional tax payment. You can revise your investment decisions until you press the "ENTER" button. By pressing the button "See results of previous rounds" you can view your profits and losses actually accrued in previous periods.

\section{At the end of each period you will be informed of the following infor- mation}

- Profit-loss-situation

- Shift detected by tax authorities (if any)

- Loss carry-forwards

- Your net result

- Remuneration for the period (in Eurocent)

- Detailed calculation of net result

Then the next period begins. Again you make decisions concerning alternatives for investment and action. However, you cannot enter the next round until all participants have completed the round concerned.

Please note that any loss carry-forward and group taxation run for five periods. This means that if you have opted for group taxation in one of the last four periods you automatically enter case (2.1). In this case it is also indicated how many rounds group taxation has already been used. After these five periods the separate accounting option becomes available again.

Loss carry-forwards in an investment object are utilized if a profit is accrued in a current period. The amount of losses to be carried forward is shown on screen at all times. 
Please also note that any profit shifts made via use of accounting leeway must always fall below the profit of IO II, or if group taxation is used of both IO's, resulting from the allocation of production factors as chosen.

Your remuneration for the period results from the net profit (total after-tax return minus any additional tax payments) that you have produced. In each period the return you achieved in excess of 16,000 is converted into Euro at a fixed exchange rate. 110 units of the difference to 16.000 correspond of one cent. If you achieved 16,000 or less or even a loss your compensation for this period is zero. 


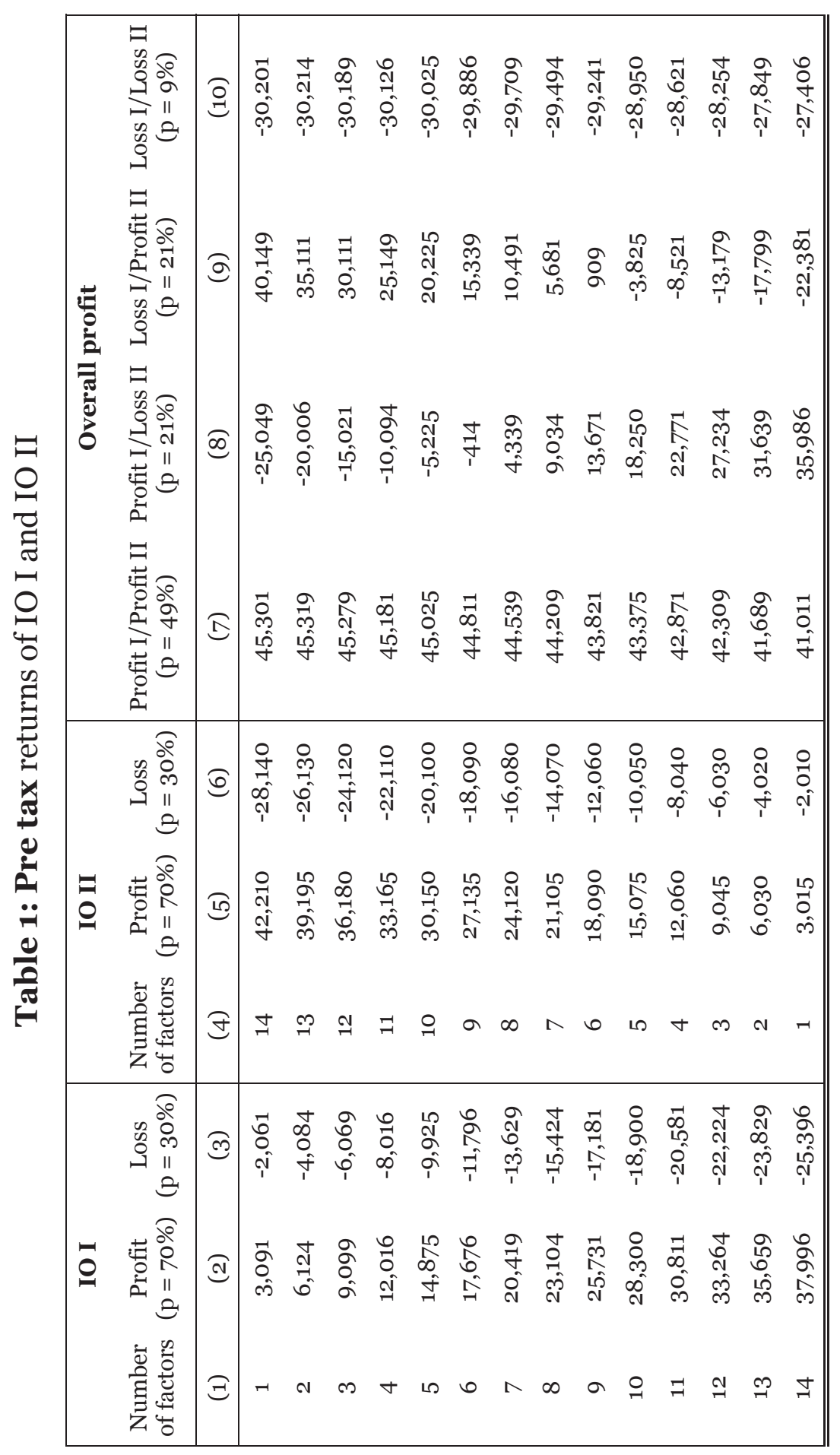




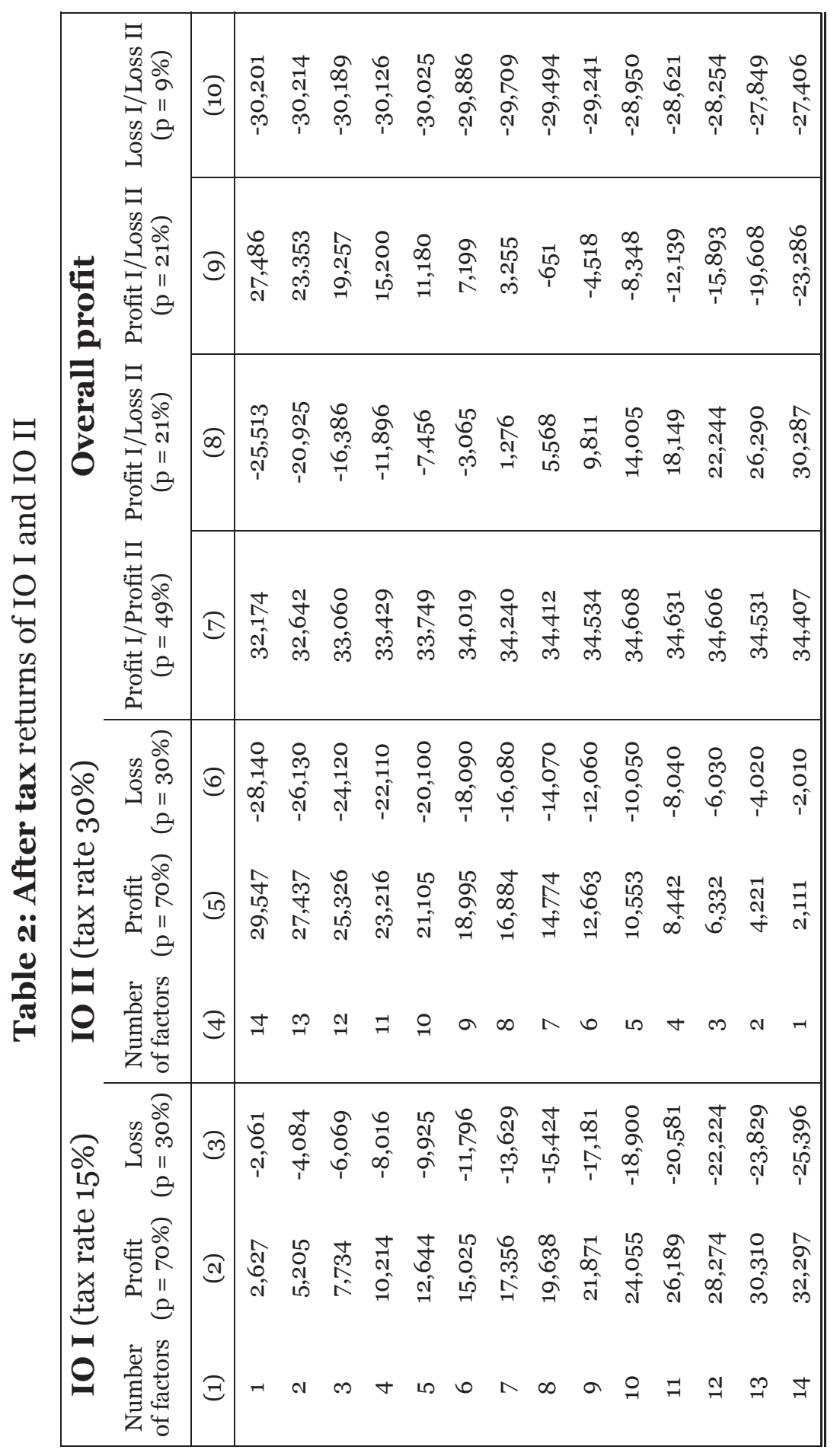




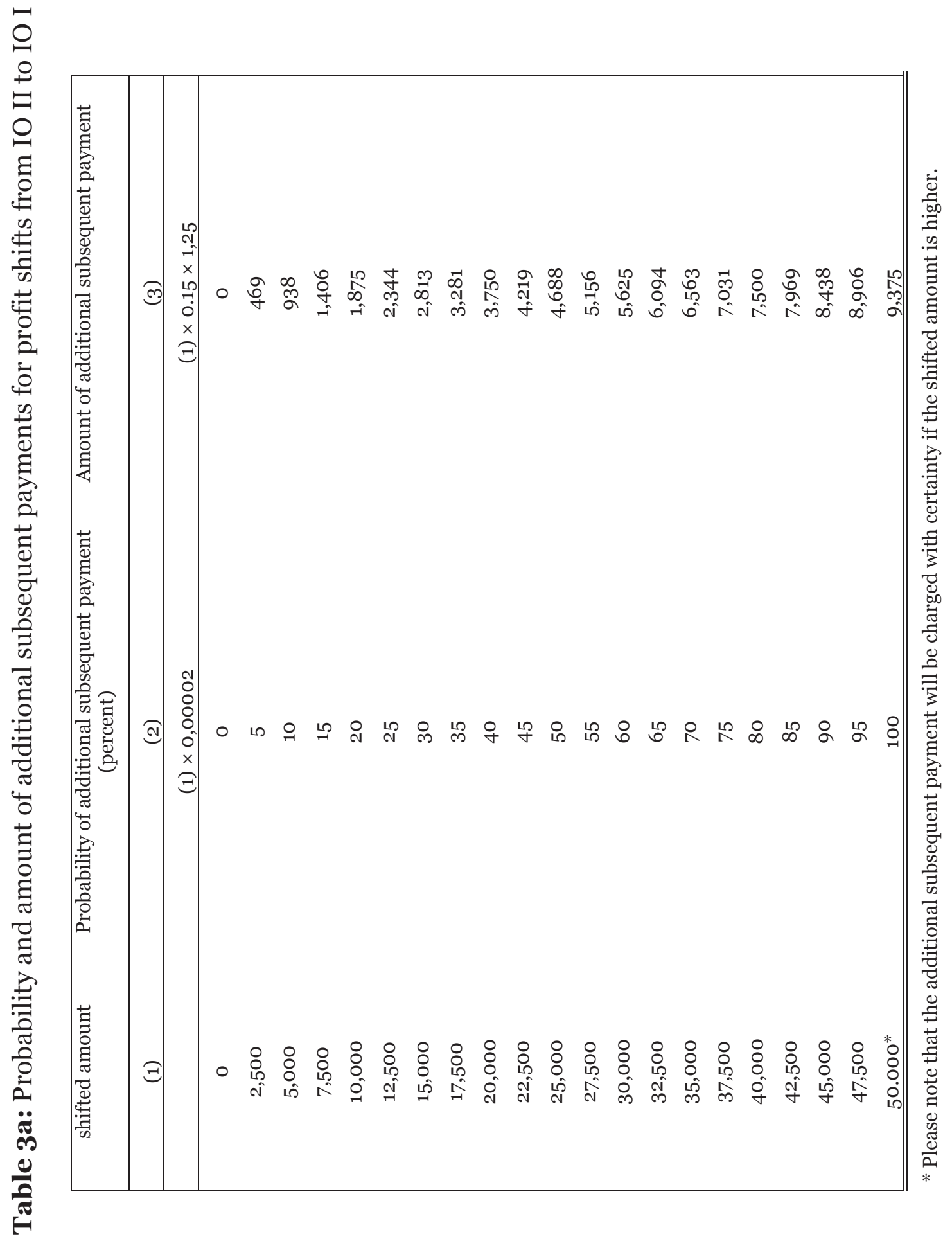




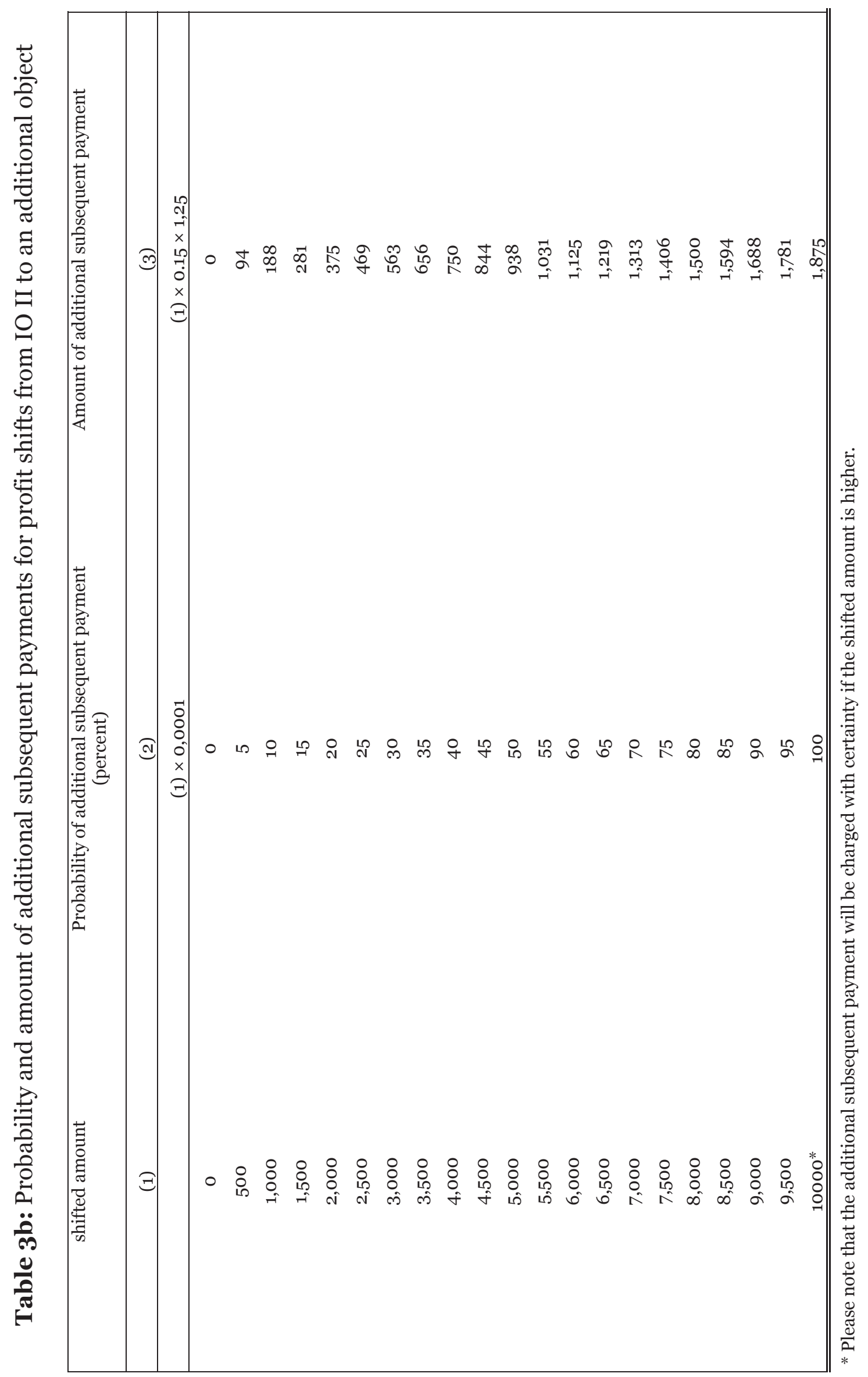




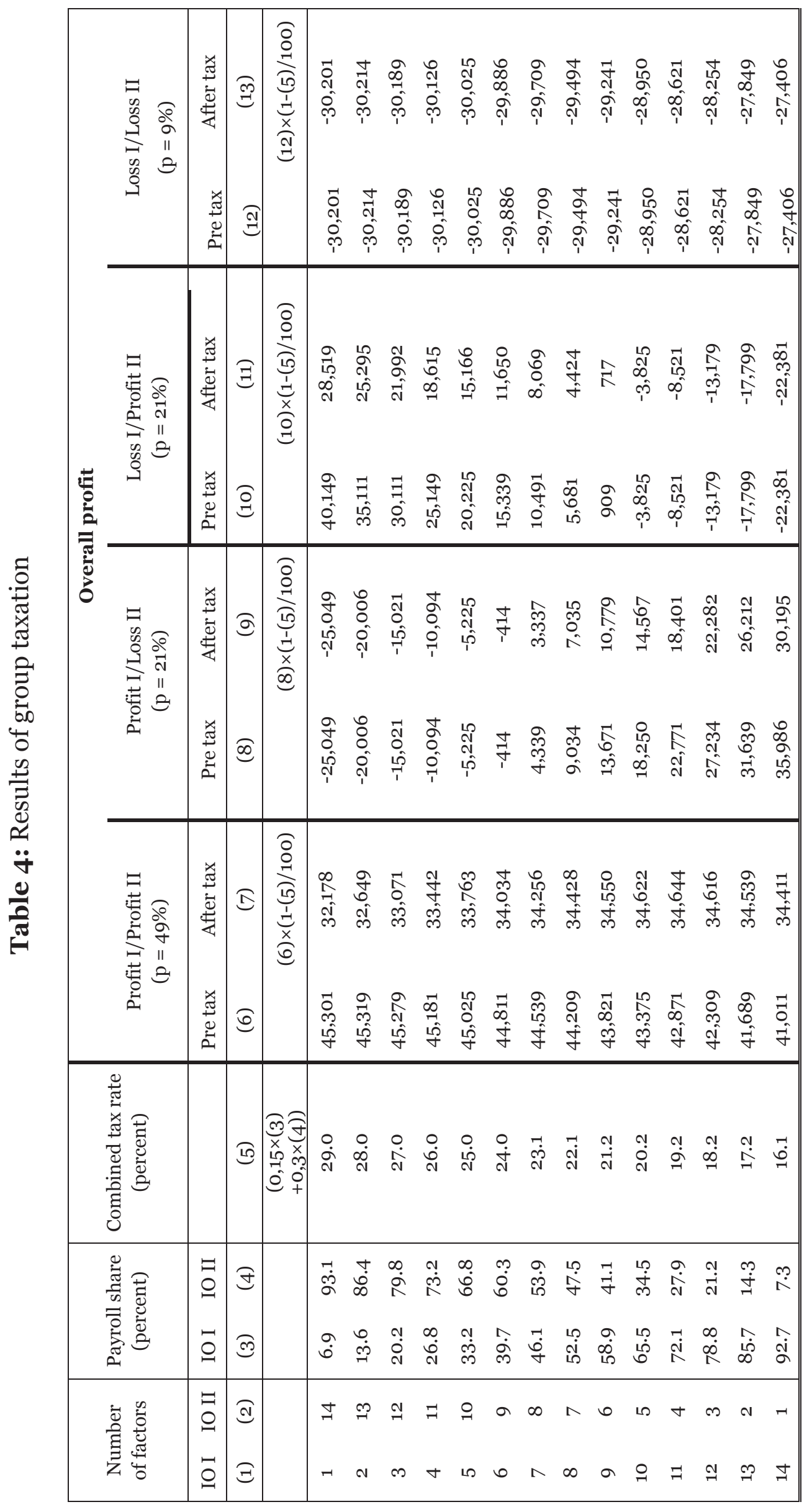




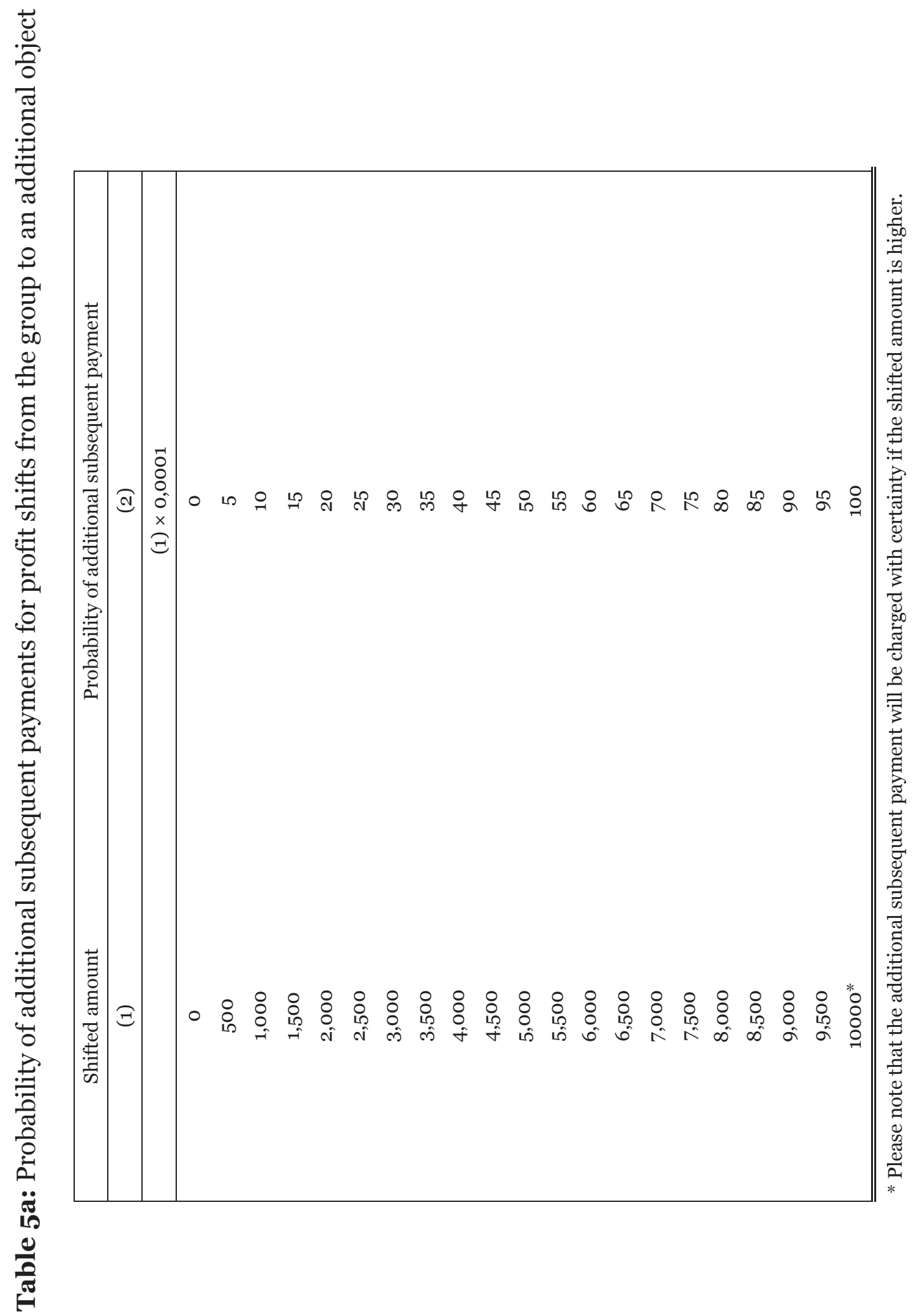


The CCCTB option - an experimental study

Claudia Keser, Gerrit Kimpel and Andreas Oestreicher

Appendix B: Regression Results 
Table B.1: Choice of formula apportioment as the tax regime (Regression model 1)

\begin{tabular}{|c|c|}
\hline Variables & $1=\mathrm{FA}$ \\
\hline LCF at IO I & $\begin{array}{l}-0.0999 \\
(0.0954)\end{array}$ \\
\hline LCF at IO II & $\begin{array}{l}-0.371^{* * *} \\
(0.0704)\end{array}$ \\
\hline LCF at group level & $\begin{array}{l}0.239^{* * * *} \\
(0.0827)\end{array}$ \\
\hline TD15 & $\begin{array}{c}0.308 \\
(0.253)\end{array}$ \\
\hline Manager & $\begin{array}{l}0.0630 \\
(0.265)\end{array}$ \\
\hline Gender & $\begin{array}{l}-0.313 \\
(0.271)\end{array}$ \\
\hline Business Experience & $\begin{array}{c}-1.130^{* * *} \\
(0.335)\end{array}$ \\
\hline Risk level & $\begin{array}{l}-0.0677 \\
(0.0774)\end{array}$ \\
\hline Time & $\begin{array}{l}-0.00854^{*} \\
(0.00508)\end{array}$ \\
\hline Period & $\begin{array}{c}0.0472^{* * *} \\
(0.0124)\end{array}$ \\
\hline Master & $\begin{array}{c}0.979^{* * *} \\
(0.290)\end{array}$ \\
\hline Impulsivity & $\begin{array}{c}0.134^{*} \\
(0.0807)\end{array}$ \\
\hline Age & $\begin{array}{l}-0.00417 \\
(0.00910)\end{array}$ \\
\hline Business Administration & $\begin{array}{l}-0.446 \\
(0.360)\end{array}$ \\
\hline Economics & $\begin{array}{c}-0.527 \\
(0.396)\end{array}$ \\
\hline Other & \\
\hline Tax return prepared & $\begin{array}{c}0.408 \\
(0.288)\end{array}$ \\
\hline Constant & $\begin{array}{l}-0.830 \\
(0.675)\end{array}$ \\
\hline $\begin{array}{l}\text { Pseudo } \mathrm{R}^{2} \\
\text { Observation } \\
\text { Standard errors }\end{array}$ & $\begin{array}{c}0.280 \\
982 \\
\text { cluster robust }\end{array}$ \\
\hline
\end{tabular}

Statistical significance at the $1 \%, 5 \%$ and $10 \%$ are denoted by ***, ${ }^{* *}$ and ${ }^{*}$, respectively. 
Table B.2: Allocation of production factors

\begin{tabular}{|c|c|c|c|}
\hline Variables & Overall & SA & FA \\
\hline LCF at IO I & $\begin{array}{l}-0.0546 \\
(0.0434)\end{array}$ & $\begin{array}{l}-0.0983^{*} \\
(0.0513)\end{array}$ & \\
\hline LCF at IO II & $\begin{array}{l}0.0231^{*} \\
(0.0126)\end{array}$ & $\begin{array}{l}0.0249^{* *} \\
(0.0119)\end{array}$ & \\
\hline LCF at group level & $\begin{array}{l}0.00957 \\
(0.0215)\end{array}$ & & $\begin{array}{c}0.0105 \\
(0.0252)\end{array}$ \\
\hline TD15 & $\begin{array}{c}-0.343^{* * * *} \\
(0.0933)\end{array}$ & $\begin{array}{c}-0.240^{* *} \\
(0.108)\end{array}$ & $\begin{array}{c}-0.546^{* * * *} \\
(0.147)\end{array}$ \\
\hline Manager & $\begin{array}{c}-0.126 \\
(0.0860)\end{array}$ & $\begin{array}{c}-0.106 \\
(0.0777)\end{array}$ & $\begin{array}{c}0.498^{* * *} \\
(0.174)\end{array}$ \\
\hline FA & $\begin{array}{l}-0.237^{*} \\
(0.122)\end{array}$ & & \\
\hline FA $*$ Manager & $\begin{array}{c}0.595^{* * *} \\
(0.169)\end{array}$ & & \\
\hline Transfer to IO I & $\begin{array}{l}0.0256^{* * * *} \\
(0.00532)\end{array}$ & $\begin{array}{l}0.0227^{* * *} \\
(0.00446)\end{array}$ & \\
\hline Transfer to $\mathrm{Z}$ & $\begin{array}{l}0.0245^{* * *} \\
(0.00568)\end{array}$ & $\begin{array}{l}0.0325^{* * *} \\
(0.00786)\end{array}$ & $\begin{array}{l}0.0257^{* * *} \\
(0.00877)\end{array}$ \\
\hline Detection of transfer to IO I & $\begin{array}{l}0.00273 \\
(0.0622)\end{array}$ & $\begin{array}{l}-0.0178 \\
(0.0548)\end{array}$ & \\
\hline Detection of transfer to $\mathrm{Z}$ & $\begin{array}{l}-0.0156 \\
(0.0742)\end{array}$ & $\begin{array}{c}0.0392 \\
(0.0663)\end{array}$ & $\begin{array}{l}-0.101 \\
(0.138)\end{array}$ \\
\hline Gender & $\begin{array}{l}-0.0333 \\
(0.0926)\end{array}$ & $\begin{array}{c}-0.0512 \\
(0.114)\end{array}$ & $\begin{array}{c}0.00769 \\
(0.149)\end{array}$ \\
\hline Business Experience & $\begin{array}{l}0.0528 \\
(0.124)\end{array}$ & $\begin{array}{c}-0.0107 \\
(0.141)\end{array}$ & $\begin{array}{c}0.224 \\
(0.268)\end{array}$ \\
\hline Risk level & $\begin{array}{l}-0.0338 \\
\text { (0.0261) }\end{array}$ & $\begin{array}{l}-0.0431 \\
(0.0316)\end{array}$ & $\begin{array}{c}0.0137 \\
(0.0421)\end{array}$ \\
\hline Time & $\begin{array}{c}0.00112 \\
(0.00106)\end{array}$ & $\begin{array}{c}-0.000444 \\
(0.000965)\end{array}$ & $\begin{array}{c}0.00380 \\
(0.00239)\end{array}$ \\
\hline Period & $\begin{array}{l}0.000146 \\
(0.00557)\end{array}$ & $\begin{array}{c}0.00748 \\
(0.00599)\end{array}$ & $\begin{array}{l}-0.0109 \\
(0.0109)\end{array}$ \\
\hline Master & $\begin{array}{l}-0.108 \\
(0.105)\end{array}$ & $\begin{array}{l}-0.114 \\
(0.134)\end{array}$ & $\begin{array}{l}-0.175 \\
(0.157)\end{array}$ \\
\hline Impulsivity & $\begin{array}{l}-0.0228 \\
(0.0269)\end{array}$ & $\begin{array}{l}-0.0191 \\
(0.0331)\end{array}$ & $\begin{array}{l}-0.0480 \\
(0.0387)\end{array}$ \\
\hline Age & $\begin{array}{l}-0.0113^{* * * *} \\
(0.00350)\end{array}$ & $\begin{array}{l}-0.00767 \\
(0.00540)\end{array}$ & $\begin{array}{l}-0.00861^{*} \\
(0.00494)\end{array}$ \\
\hline Business Administration & $\begin{array}{c}-0.0182 \\
(0.152)\end{array}$ & $\begin{array}{l}-0.116 \\
(0.134)\end{array}$ & $\begin{array}{c}0.262 \\
(0.305)\end{array}$ \\
\hline Economics & $\begin{array}{l}0.0948 \\
(0.165)\end{array}$ & $\begin{array}{c}0.108 \\
(0.142)\end{array}$ & $\begin{array}{c}0.180 \\
(0.264)\end{array}$ \\
\hline Other & & & \\
\hline Tax return prepared & $\begin{array}{l}-0.0145 \\
(0.104)\end{array}$ & $\begin{array}{c}0.00886 \\
(0.101)\end{array}$ & $\begin{array}{l}-0.127 \\
(0.207)\end{array}$ \\
\hline Constant & $\begin{array}{c}2.591^{* * *} \\
(0.228)\end{array}$ & $\begin{array}{c}2.457^{* * *} \\
(0.259)\end{array}$ & $\begin{array}{c}2.278^{* * *} \\
(0.441)\end{array}$ \\
\hline Lnalpha & $\begin{array}{c}-1.495^{* * *} \\
(0.273)\end{array}$ & $\begin{array}{c}-1.943^{* * *} \\
(0.405)\end{array}$ & $\begin{array}{c}-1.172^{* * *} \\
(0.387)\end{array}$ \\
\hline $\begin{array}{l}\text { Observation } \\
\text { Standard errors }\end{array}$ & $\begin{array}{c}1.245 \\
\text { cluster robust }\end{array}$ & $\begin{array}{c}738 \\
\text { cluster robust }\end{array}$ & $\begin{array}{c}507 \\
\text { cluster robust }\end{array}$ \\
\hline
\end{tabular}


Table B.3: Profit shifts to IO 1

\begin{tabular}{|c|c|}
\hline Variables & LN profit shift to $\mathrm{IO}_{1}$ \\
\hline $\mathrm{LCF}$ at IO I & $\begin{array}{c}-0.127 \\
(0.0863)\end{array}$ \\
\hline LCF at IO II & $\begin{array}{l}-0.256^{* * *} \\
(0.0750)\end{array}$ \\
\hline TD15 & $\begin{array}{l}-1.265^{*} \\
(0.742)\end{array}$ \\
\hline Manager & $\begin{array}{l}1.183^{*} \\
(0.669)\end{array}$ \\
\hline Investment in IO II & $\begin{array}{l}0.127^{* * *} \\
(0.0498)\end{array}$ \\
\hline Transfer to Z & $\begin{array}{l}0.0993 \\
(0.158)\end{array}$ \\
\hline Detection of transfer to IO I & $\begin{array}{l}0.713^{*} \\
(0.392)\end{array}$ \\
\hline Detection of transfer to $\mathrm{Z}$ & $\begin{array}{l}-1.134^{* *} \\
(0.512)\end{array}$ \\
\hline Gender & $\begin{array}{c}-1.450^{* *} \\
(0.736)\end{array}$ \\
\hline Business Experience & $\begin{array}{l}-1.719^{*} \\
(0.912)\end{array}$ \\
\hline Risk level & $\begin{array}{l}0.386^{*} \\
(0.205)\end{array}$ \\
\hline Time & $\begin{array}{l}-0.00985 \\
(0.00724)\end{array}$ \\
\hline Period & $\begin{array}{l}-0.0437 \\
(0.0397)\end{array}$ \\
\hline Master & $\begin{array}{c}2.403^{* * *} \\
(0.791)\end{array}$ \\
\hline Impulsivity & $\begin{array}{c}0.197 \\
(0.221)\end{array}$ \\
\hline . & $\begin{array}{l}0.00849 \\
(0.0352)\end{array}$ \\
\hline Business Administration & $\begin{array}{c}-0.971 \\
(0.987)\end{array}$ \\
\hline Economics & $\begin{array}{c}-2.879^{* *} \\
(1.133)\end{array}$ \\
\hline Other & \\
\hline Tax return prepared & $\begin{array}{c}0.785 \\
(0.903)\end{array}$ \\
\hline Constant & $\begin{array}{c}3.415 \\
(2.102)\end{array}$ \\
\hline $\mathrm{R}^{2}$ & 0.2645 \\
\hline Observation & 738 \\
\hline Standard errors & cluster robust \\
\hline
\end{tabular}


Table B.4: Profit shifts to the additional investment object Z

\begin{tabular}{|c|c|c|c|}
\hline Variables & Overall & $\begin{array}{c}\mathrm{LN} \text { transfer to } \mathrm{Z} \\
\text { SA }\end{array}$ & FA \\
\hline LCF at IO I & $\begin{array}{l}-0.110^{* *} \\
(0.0516)\end{array}$ & $\begin{array}{c}-0.0875 \\
(0.0556)\end{array}$ & \\
\hline LCF at IO II & $\begin{array}{l}-0.146^{* *} \\
(0.0739)\end{array}$ & $\begin{array}{l}-0.135^{*} \\
(0.0702)\end{array}$ & \\
\hline LCF at group level & $\begin{array}{c}-0.262^{* *} \\
(0.123)\end{array}$ & & $\begin{array}{c}-0.289^{* *} \\
(0.143)\end{array}$ \\
\hline TD15 & $\begin{array}{l}-0.642 \\
(0.610)\end{array}$ & $\begin{array}{l}-1.259^{*} \\
(0.655)\end{array}$ & $\begin{array}{c}-0.118 \\
(0.801)\end{array}$ \\
\hline Manager & $\begin{array}{c}0.299 \\
(0.573)\end{array}$ & $\begin{array}{c}0.328 \\
(0.636)\end{array}$ & $\begin{array}{c}0.241 \\
(0.813)\end{array}$ \\
\hline FA & $\begin{array}{l}1.811^{* * *} \\
(0.420)\end{array}$ & & \\
\hline Transfer to IO I & $\begin{array}{c}0.0405 \\
(0.0396)\end{array}$ & $\begin{array}{c}0.0600 \\
(0.0451)\end{array}$ & \\
\hline Investment in IO II & $\begin{array}{l}-0.00663 \\
(0.0313)\end{array}$ & $\begin{array}{l}-0.0304 \\
(0.0420)\end{array}$ & $\begin{array}{c}0.0187 \\
(0.0389)\end{array}$ \\
\hline Detection of transfer to IO I & $\begin{array}{l}0.0214 \\
(0.313)\end{array}$ & $\begin{array}{c}-0.151 \\
(0.306)\end{array}$ & \\
\hline Detection of transfer to Z & $\begin{array}{c}0.421 \\
(0.298)\end{array}$ & $\begin{array}{c}0.112 \\
(0.490)\end{array}$ & $\begin{array}{c}0.354 \\
(0.398)\end{array}$ \\
\hline Gender & $\begin{array}{l}-1.179^{*} \\
(0.631)\end{array}$ & $\begin{array}{c}-1.162 \\
(0.723)\end{array}$ & $\begin{array}{c}-0.972 \\
(0.868)\end{array}$ \\
\hline Business Experience & $\begin{array}{c}0.177 \\
(0.666)\end{array}$ & $\begin{array}{c}0.324 \\
(0.757)\end{array}$ & $\begin{array}{l}-1.992^{* *} \\
(0.929)\end{array}$ \\
\hline Risk level & $\begin{array}{l}0.336^{* *} \\
(0.160)\end{array}$ & $\begin{array}{l}0.340^{*} \\
(0.185)\end{array}$ & $\begin{array}{l}0.0752 \\
(0.203)\end{array}$ \\
\hline Time & $\begin{array}{c}-0.00910^{* * *} \\
(0.00349)\end{array}$ & $\begin{array}{l}-0.00583 \\
(0.00474)\end{array}$ & $\begin{array}{l}-0.0147^{*} \\
(0.00791)\end{array}$ \\
\hline Period & $\begin{array}{c}-0.00917 \\
(0.0233)\end{array}$ & $\begin{array}{l}-0.0164 \\
(0.0278)\end{array}$ & $\begin{array}{l}-0.0130 \\
(0.0403)\end{array}$ \\
\hline Master & $\begin{array}{c}0.158 \\
(0.735)\end{array}$ & $\begin{array}{c}0.996 \\
(0.950)\end{array}$ & $\begin{array}{c}-0.0592 \\
(0.914)\end{array}$ \\
\hline Impulsivity & $\begin{array}{c}0.283 \\
(0.196)\end{array}$ & $\begin{array}{l}0.0543 \\
(0.219)\end{array}$ & $\begin{array}{l}0.610^{* *} \\
(0.291)\end{array}$ \\
\hline Age & $\begin{array}{c}0.0240 \\
(0.0305)\end{array}$ & $\begin{array}{c}0.0149 \\
(0.0429)\end{array}$ & $\begin{array}{c}0.0259 \\
(0.0273)\end{array}$ \\
\hline Business Administration & $\begin{array}{c}0.277 \\
(1.059)\end{array}$ & $\begin{array}{l}-0.373 \\
(1.323)\end{array}$ & $\begin{array}{l}-0.744 \\
(1.243)\end{array}$ \\
\hline Economics & $\begin{array}{c}0.251 \\
(1.107)\end{array}$ & $\begin{array}{c}-1.129 \\
(1.330)\end{array}$ & $\begin{array}{c}0.126 \\
(1.261)\end{array}$ \\
\hline Other & & & \\
\hline Tax return prepared & $\begin{array}{c}0.895 \\
(0.753)\end{array}$ & $\begin{array}{c}1.274 \\
(0.849)\end{array}$ & $\begin{array}{c}1.071 \\
(1.175)\end{array}$ \\
\hline Constant & $\begin{array}{l}-0.207 \\
(1.722)\end{array}$ & $\begin{array}{c}1.996 \\
(2.121)\end{array}$ & $\begin{array}{c}1.501 \\
(2.125)\end{array}$ \\
\hline $\begin{array}{l}\mathrm{R}^{2} \\
\text { Observation } \\
\text { Standard errors }\end{array}$ & $\begin{array}{c}0.1948 \\
1.245 \\
\text { cluster robust }\end{array}$ & $\begin{array}{c}0.1789 \\
738 \\
\text { cluster robust }\end{array}$ & $\begin{array}{c}0.2134 \\
507 \\
\text { cluster robust }\end{array}$ \\
\hline
\end{tabular}

Statistical significance at the $1 \%, 5 \%$ and $10 \%$ are denoted by ${ }^{* * *},{ }^{* *}$ and ${ }^{*}$, respectively. 